\title{
Modern Landscape Processes Affecting Archaeological Sites along the Colorado River Corridor Downstream of Glen Canyon Dam, Glen Canyon National Recreation Area, Arizona
}

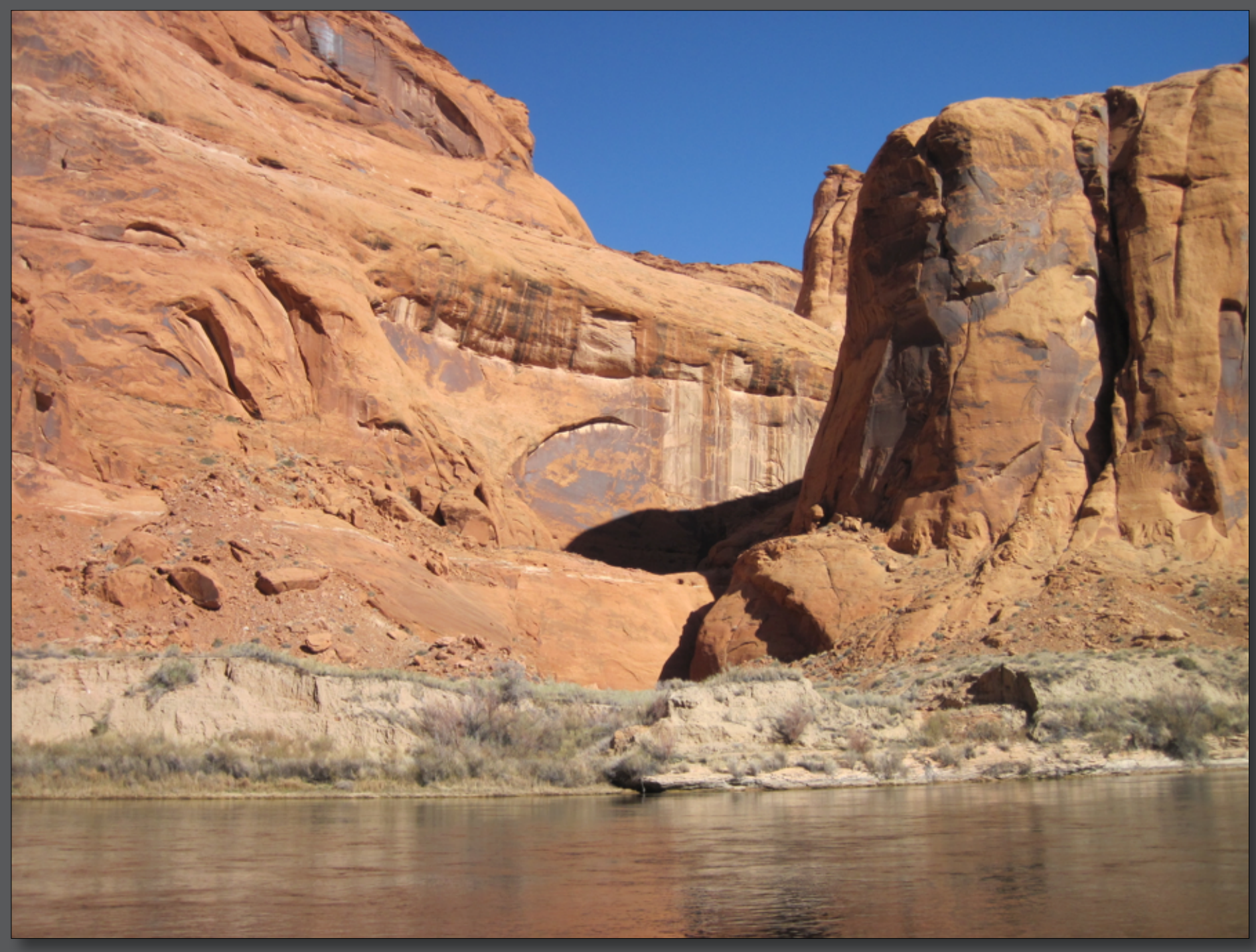

Scientific Investigations Report 2017-5082 
Cover. Relict sedimentary terraces along the Colorado River corridor downstream of Glen Canyon Dam, Arizona. 


\section{Modern Landscape Processes Affecting Archaeological Sites along the Colorado River Corridor Downstream of Glen Canyon Dam, Glen Canyon National Recreation Area, Arizona}

By Amy E. East, Joel B. Sankey, Helen C. Fairley, Joshua J. Caster, and Alan Kasprak

Scientific Investigations Report 2017-5082 


\title{
U.S. Department of the Interior \\ RYAN K. ZINKE, Secretary
}

\section{U.S. Geological Survey \\ William Werkheiser, Acting Director}

\author{
U.S. Geological Survey, Reston, Virginia: 2017
}

For more information on the USGS - the Federal source for science about the Earth, its natural and living resources, natural hazards, and the environment-visit https://www.usgs.gov/ or call 1-888-ASK-USGS.

For an overview of USGS information products, including maps, imagery, and publications,

visit https://store.usgs.gov.

Any use of trade, firm, or product names is for descriptive purposes only and does not imply endorsement by the U.S. Government.

Although this information product, for the most part, is in the public domain, it also may contain copyrighted materials as noted in the text. Permission to reproduce copyrighted items must be secured from the copyright owner.

Suggested citation:

East, A.E., Sankey, J.B., Fairley, H.C., Caster, J.J., and Kasprak, A., 2017, Modern landscape processes affecting archaeological sites along the Colorado River corridor downstream of Glen Canyon Dam, Glen Canyon National Recreation Area, Arizona: U.S. Geological Survey Scientific Investigations Report 2017-5082, 22 p., https://doi.org/10.3133/sir20175082.

ISSN 2328-0328 (online) 


\section{Contents}

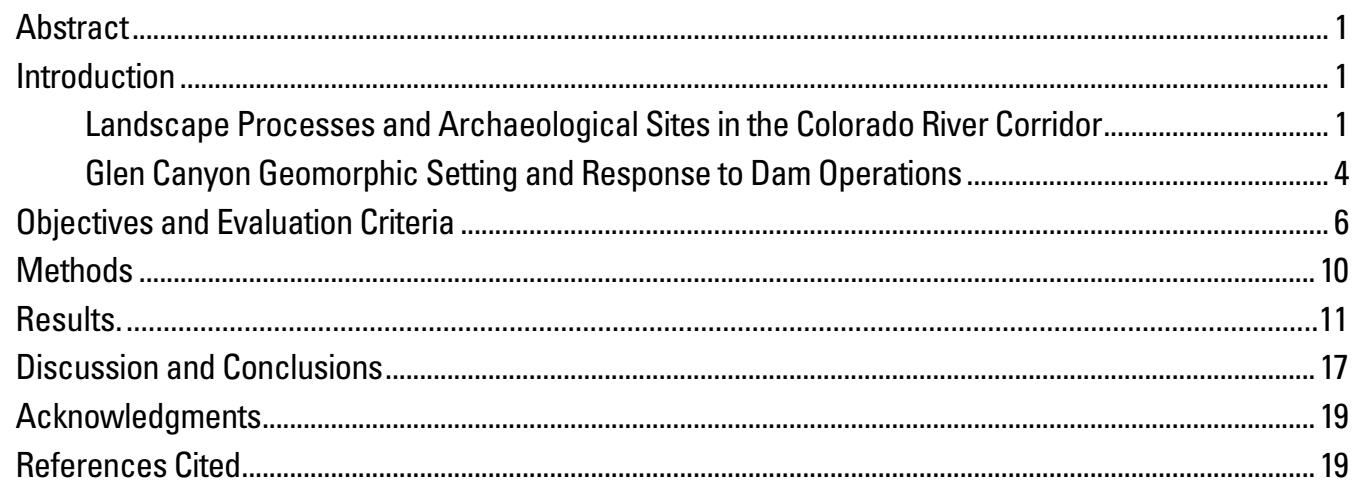

\section{Figures}

1. Map of the Colorado River corridor in northern Arizona ............................................................... 2

2. Photographs of the modern geomorphic setting and evidence of landscape processes along the Colorado River in Glen Canyon..................................................................................... 4

3. Schematic diagram illustrating the classification system used to identify potential sources of aeolian sand that could reach archaeological sites

4. Schematic diagram illustrating the classification system used to identify overland-flow drainage erosion affecting archaeological sites ................................................................... 9

5. Results of aeolian sand classification for 54 river-corridor archaeological sites in Glen Canyon ....................................................................................................................... 15

6. Results of drainage classification for 54 river-corridor archaeological sites in Glen Canyon.

\section{Tables}

1. Classification of archaeological sites based on potential aeolian sand supply ..........................

2. Classification of archaeological sites based on overland-flow drainage setting ...................... 9

3. Results of the potential aeolian sand supply and drainage classification analysis for 54 archaeological sites in Glen Canyon and uppermost Marble Canyon.. . .12

4. Summary of the number of sites within each aeolian and drainage classification type from 1952 to 2016

5. Summary of changes observed in aeolian and drainage classification types for each time interval between 1952, 1973, 1984, 1996, and 2016 



\title{
Modern Landscape Processes Affecting Archaeological Sites along the Colorado River Corridor Downstream of Glen Canyon Dam, Glen Canyon National Recreation Area, Arizona
}

\author{
By Amy E. East, Joel B. Sankey, Helen C. Fairley, Joshua J. Caster, and Alan Kasprak
}

\section{Abstract}

The landscape of the Colorado River through Glen Canyon National Recreation Area formed over many thousands of years and was modified substantially after the completion of Glen Canyon Dam in 1963. Changes to river flow, sediment supply, channel base level, lateral extent of sedimentary terraces, and vegetation in the post-dam era have modified the river-corridor landscape and have altered the effects of geologic processes that continue to shape the landscape and its cultural resources. The Glen Canyon reach of the Colorado River downstream of Glen Canyon Dam hosts many archaeological sites that are prone to erosion in this changing landscape. This study uses field evaluations from 2016 and aerial photographs from 1952, 1973, 1984, and 1996 to characterize changes in potential windblown sand supply and drainage configuration that have occurred over more than six decades at 54 archaeological sites in Glen Canyon and uppermost Marble Canyon. To assess landscape change at these sites, we use two complementary geomorphic classification systems. The first evaluates the potential for aeolian (windblown) transport of river-derived sand from the active river channel to higher-elevation archaeological sites. The second identifies whether rills, gullies, or arroyos (that is, overland drainages that erode the ground surface) exist at the archaeological sites as well as the geomorphic surface, and therefore the relative base level, to which those flow paths drain. Results of these assessments are intended to aid in the management of irreplaceable archaeological resources by the National Park Service and stakeholders of the Glen Canyon Dam Adaptive Management Program.

Currently, none of the 54 archaeological sites evaluated in this report is ideally situated to receive windblown sand from contemporary fluvial (river-deposited) sediment sources. Few sites have an upwind fluvial sandbar today and, where such a fluvial sand source is present, aeolian sand transport toward downwind archaeological sites is limited by vegetation. A majority of sites are intersected by overland-flow paths that lead to the active Colorado River channel. However, 10 sites contain drainages that currently (as of 2016) grade to pre-dam terraces and therefore have a higher effective base level than that of the active river channel. Substantial changes have occurred over several decades in the potential for aeolian sand supply to reach, and thus potentially stabilize, archaeological sites, with a clear progression toward decreased potential for windblown sand supply at many sites. We identify few instances in which the overland-flow drainage pattern changed over time such that gullies began to grade to a new, lower base level; however, our analysis of possible changes in drainage configuration is limited by poor resolution and restricted spatial coverage of the two earliest aerial photograph sets. Nonetheless, some of the archaeological sites exhibit changes that indicate a transition to a more degraded condition and may therefore warrant detailed topographic monitoring beyond simple monitoring of changes in site classification (for example, to quantify the growth of pre-existing gullies or erosion of terrace cutbanks).

\section{Introduction}

\section{Landscape Processes and Archaeological Sites in the Colorado River Corridor}

The physical, ecological, and cultural landscape of the Colorado River corridor through Glen Canyon National Recreation Area (fig. 1), which formed over many thousands of years, was modified substantially after the completion of Glen Canyon Dam in 1963. Changes to the flow and sediment supply of the Colorado River owing to dam operations profoundly affected the structure and function of the downstream landscape and ecosystem, leading to lowered riverbed elevation, reduced size and numbers of fluvial (river-formed) sandbars, changes in aeolian (windblown) sand supply, increased riparian vegetation growth, and alterations in the aquatic and riparian food web (Turner and Karpiscak, 1980; Schmidt and Graf, 1990; Topping and others, 2000; Rubin and others, 2002; Hazel and others, 2006; Grams and others, 2007; Kennedy and Ralston, 2012; Cross and others, 2013; Sankey and others, 2015).

These changes, in turn, have altered landscape processes in upland areas (that is, above the modern dam-controlled flood stage corresponding to a discharge of approximately 1,270 cubic meters per second, $\mathrm{m}^{3} / \mathrm{s}$ ), with important implications for historic and prehistoric cultural resources (for example, East and others, 2016). Archaeological sites in the river corridor of Glen, Marble, and Grand Canyons commonly occur on and within fluvial and aeolian fine-grained sediment deposits derived from the Colorado River 
Modern Landscape Processes Affecting Archaeological Sites along the Colorado River Corridor, Arizona
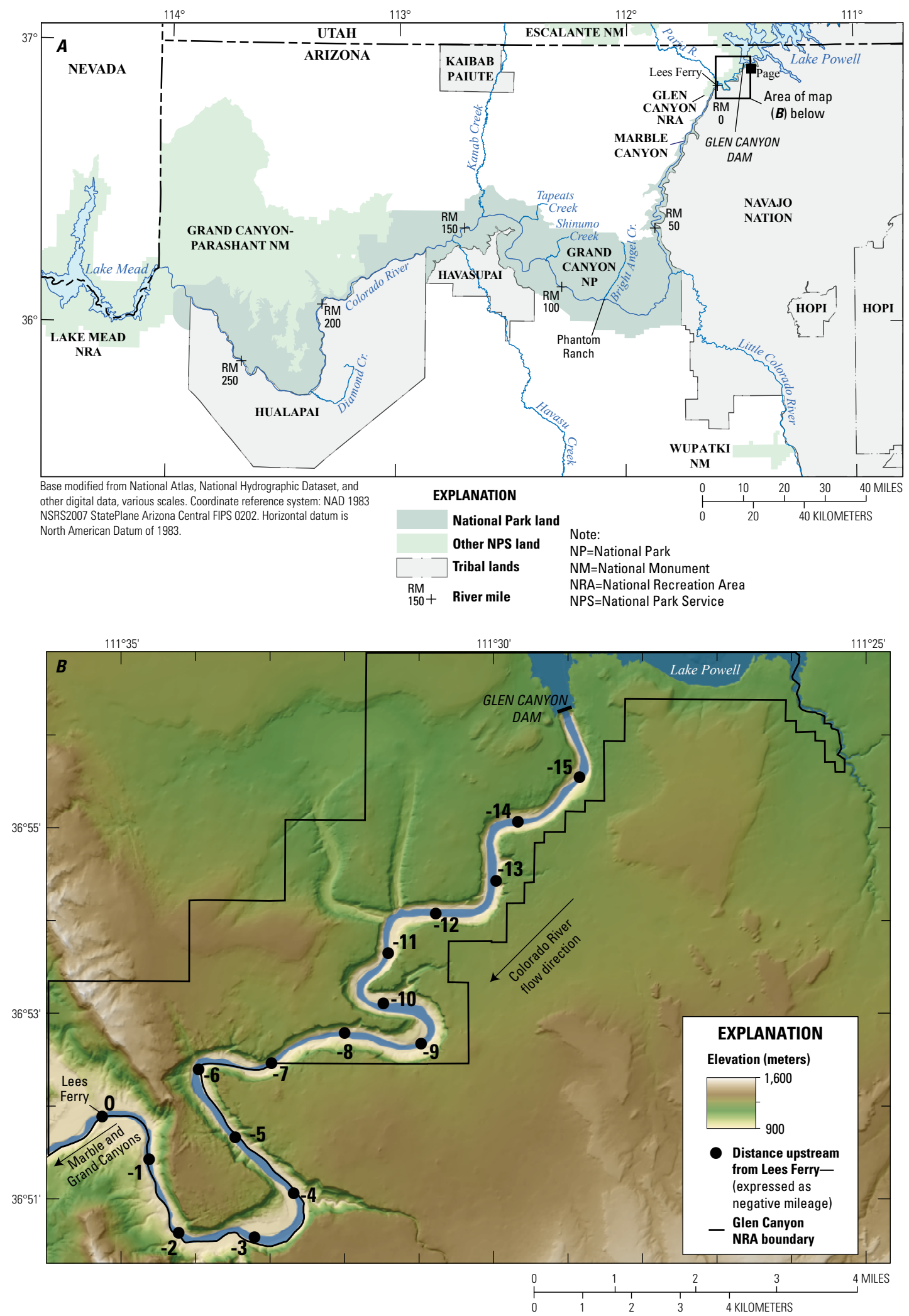

Figure 1. Map of the Colorado River corridor in northern Arizona. A, Map of the Colorado River corridor downstream of Glen Canyon Dam. By convention, distance along the river is indicated by river miles (RM), where mileage increases with distance downstream of Lees Ferry (RM 0). Glen Canyon Dam occurs at RM -15. The river corridor upstream of Lees Ferry is managed as part of Glen Canyon National Recreation Area; the portion downstream from Lees Ferry, including Marble and Grand Canyons, is managed by Grand Canyon National Park. Area of detail shown in $B$ indicated by the red box. $B$, Map showing detail of the Glen Canyon reach, between Glen Canyon Dam and Lees Ferry. 
(Hereford and others, 1993; Fairley and others, 1994; Hereford and others, 2000; Fairley and Hereford, 2002; Anderson, 2006; Draut and others, 2008; Anderson and Neff, 2011; Pederson and others, 2011; Pederson and O'Brien, 2014). Sedimentary deposits of this sort formed largely from episodic flood deposition over thousands of years, and were modified during the intervening periods by wind and hillslope runoff (overland flow resulting from excess rainfall) between those large landscape-modifying floods. The geomorphic stability (that is, resistance to erosion) of sand-dominated sediment deposits, and the stability of the several hundred archaeological sites within them, depends in part upon the balance between the sediment supplied and removed by wind and water (Pederson and O'Brien, 2014; East and others, 2016).

Water- and wind-driven landscape erosion are natural processes that act over time. In the southwestern United States, fluvial and aeolian sand deposits degrade as wind and rainfall runoff entrain and remove sediment. In the case of archeological sites along the Colorado River, as overland flow channelizes into rills, gullies, and arroyos (henceforth collectively referred to as drainages), surface runoff can contribute substantially to erosion of these sites (Hereford and others, 1993; Pederson and others, 2006; Collins and others, 2009, 2012, 2016; Pederson and O'Brien, 2014).

Drainage development is a complex function of rainfall intensity, sediment infiltration capacity, and upslope catchment (drainage basin) area. In Colorado River sand deposits, drainages commonly form and evolve in response to overland flow from upslope areas mantled by relatively impermeable colluvium and bedrock. Because upslope catchment areas can be fairly large (on the order of 10-100 square meters, $\mathrm{m}^{2}$ ) and impermeable, rainfall runoff can incise drainages into sand deposits, even when the rainfall intensity and infiltration capacity of the sand itself would have precluded erosion by overland flow (Collins and others, 2016). Drainage erosion has damaged numerous archeological sites in the river corridor downstream of Lake Powell and upstream of Lake Mead (Hereford and others, 1993; Pederson and others, 2006; Collins and others, 2009, 2014). However, in regions of the Colorado River corridor (including Marble and Grand Canyon) that have abundant aeolian sand activity, windblown sand can limit drainage formation and can anneal (fill in) drainages, thereby substantially counteracting gully erosion (Sankey and Draut, 2014). The spatial extent and severity of drainage erosion in Colorado River sediment deposits today is likely exacerbated by reduced aeolian sand supply (East and others, 2016). Additionally, in Glen Canyon, the river channel has incised significantly downstream of the dam (Grams and others, 2007), thereby lowering the base level of the river. This induces drainages to incise more deeply into pre-dam sand deposits as the drainages grade to the deeper post-dam Colorado River base level (Hereford and others, 1993). Erosion by direct contact with the mainstem river can also cause substantial lateral retreat of sedimentary terrace margins through bank undercutting and excess pore water pressure- - a process that began with intentional channel-scouring high flows shortly after dam closure (discussed further below) (Wulf and Moss, 2004; Grams and others, 2007; East and others, 2016).
In an unregulated river system, landscape erosion by overland flow and wind deflation is counteracted to some degree by episodic large river floods and subsequent aeolian sand influx to the landscape (Thompson and Potochnik, 2000; Draut, 2012). In the pre-dam Colorado River, sediment-rich floods brought new sand into Glen, Marble, and Grand Canyons and deposited that sand on fluvial terraces - thereby filling rills, gullies, and arroyos - as well as in river eddies and along the mainstem channel margins. In many places, wind can also redistribute much of that sand to upland landscapes (areas above the elevation of dam-controlled flows), as occurs today in some areas of Marble and Grand Canyons (Draut, 2012; East and others, 2016). Thus, upland landscapes in an unregulated river corridor can receive new sediment supply both directly - from flood deposition that fills drainages and resurfaces terraces—and indirectly—from aeolian transport of flood-deposited sand from lower elevations. However, the modern dam-controlled Colorado River downstream of Glen Canyon Dam lacks the large-magnitude, sediment-rich floods required to infill drainages and deposit new sediment on fluvial terraces. The prevalence of aeolian sand sources in the river corridor is greatly reduced now compared to pre-dam time or even to the post-dam 1970s and 1980s, owing to the loss of open unvegetated sandbars, channel margins, and terraces in recent decades (Sankey and others, 2015; East and others, 2016).

The loss of sand supply to fluvial and aeolian deposits owing to Glen Canyon Dam operations, and thus the increased potential for erosion of those sand resources that do exist in Glen Canyon, has important consequences for the preservation of archaeological sites. The unique setting of the Glen Canyon reach, with geomorphology distinct from that of Marble and Grand Canyons, together with its position just downstream of the dam, have led to especially pronounced effects of dam operations there (discussed further in the next section). The cumulative effects of past, present, and future dam operations on archaeological site preservation in Glen Canyon are of concern to the Glen Canyon Dam Adaptive Management Program (GCDAMP) stakeholders, Native American tribes, and Federal and State agencies that have responsibility or concern for the management of the river corridor, archaeological sites, and dam operations. Under 54 U.S.C. $\S \S 306101-306114$, commonly known as section 106 and section 110 of the National Historic Preservation Act, as well as the Grand Canyon Protection Act of 1992, the GCDAMP aims to reduce or otherwise mitigate the effects of dam operations on archaeological resources - with the highest priority to preserve those resources in place.

Preservation in place requires optimizing conditions that preserve the stability of upland sand deposits and reduce the potential for erosional loss of cultural resources. To that end, controlled-flood dam operations, which have occurred sporadically at Glen Canyon Dam since 1996, aim to increase the fluvial sandbar area that can supply sand to upland aeolian deposits, thereby increasing the preservation potential at archaeological sites (Draut and Rubin, 2008; Melis, 2011). To determine the effectiveness of using such flow actions to preserve archaeological sites, it is necessary to determine to what extent dam operations affect landscape processes at archaeological sites, how effectively 
dam operations without large floods (that is, pre-dam magnitude) can supply sand to upland areas, and how landscape processes have changed since dam operations began. Thus, here we focus on the ability of aeolian sand derived from the modern river to affect landscape processes at Glen Canyon archaeological sites as well as the degree to which overland-flow erosion has altered those sites. This work is a continuation of a multi-year investigation of similar processes in Marble and Grand Canyons (East and others, 2016), focusing on 54 river-corridor archaeological sites within Glen Canyon and uppermost Marble Canyon (fig. 1).

\section{Glen Canyon Geomorphic Setting and Response to Dam Operations}

Geomorphic constraints affect the transport and storage of fluvial and aeolian sand differently in the Glen Canyon reach (River Mile [RM] -15 to 0) than in either Marble Canyon or Grand Canyon downstream. Glen Canyon differs from Marble and Grand Canyons in its bedrock composition, topographic relief, tributary activity, and influence of Glen Canyon Dam operations (see summary by East and others, 2016). The sandstone bedrock walls of Glen Canyon are mechanically weak (Bursztyn and others, 2015), and thus erode to form a canyon-bound corridor in which rim-to-river relief (300-400 meters, $\mathrm{m}$ ) is much less than in downstream reaches (1,000-1,900 $\mathrm{m}$ in Marble Canyon, 1,200$2,000 \mathrm{~m}$ in Grand Canyon). The combination of homogenous, clay-poor sandstone bedrock and modest relief results in a lack of large debris fans in Glen Canyon, contrasting substantially with the pool-and-drop morphology of Marble and Grand Canyons (Melis and others, 1994; Webb and others, 2003; Griffiths and others, 2004). Lacking large debris fans, Glen Canyon does not have the debris fan-eddy complexes that form rapids and trap fluvial sand as occur in many sections of Marble and Grand Canyons (Schmidt and Graf, 1990; McGuinn-Robbins, 1995; Schmidt and Grams,
2011). Furthermore, the Colorado River in Glen Canyon has a more homogenous hydraulic regime than in Marble and Grand Canyons, where large rapids separate comparatively smooth and deep pools. Thus, most of the relict pre-dam sand storage in Glen Canyon occurs not as eddy sandbars but as thick ( $10 \mathrm{~m}$ in some places), longitudinally extensive terraces, which commonly occur atop point bars on the inside of meander bends (fig. $2 A-C$ ). These terraces, which formed during sediment-rich floods predating construction of Glen Canyon Dam, continue downstream into upper Marble Canyon.

The sediment deficit imposed by Glen Canyon Dam operations, a deficit especially pronounced in the Glen Canyon reach just downstream of the dam, began to impose profound geomorphic change even before the dam was completed in 1963. Channel incision began upon installation of the first cofferdam in 1959 and intensified in 1965 during a series of 14 pulsed flows $\left(430-1700 \mathrm{~m}^{3} / \mathrm{s}\right)$ that were intended to scour sediment from the river channel (Topping and others, 2003; Grams and others, 2007). Thus, sediment evacuation during and shortly after dam construction lowered the riverbed by 2-4 m along most of Glen Canyon, and as much as $8 \mathrm{~m}$ locally (Grams and others, 2007). Through a combination of lowered riverbed and contemporaneous backwasting (lateral retreat of terrace risers), exacerbated by subsequent high flows during the early 1980s and several high-flow experiments since 1996, the sedimentary terraces in Glen Canyon have retreated as much as tens of meters over the past several decades (Grams and others, 2007; East and others, 2016). Backwasting in the early era of dam operations was particularly severe around RM -9.7 to -10.1 , where the terrace edge on river left retreated $30 \mathrm{~m}$ between 1959 and 1965, followed by an additional $\sim 10 \mathrm{~m}$ of retreat between 1965 and 2000 (Grams and others, 2007). Other especially notable areas of post-dam erosion occur from RM -2.2 to -2.5 , from RM -10.5 to -10.6 , and around RM -13.1 (Grams and others, 2007). After cessation of the 1965 pulse

Figure 2. Photographs of the modern geomorphic setting and evidence of landscape processes along the Colorado River in Glen Canyon. A, Broad terraces composed mostly of relict fluvial sediment line much of the Glen Canyon river corridor. This photograph shows one such terrace (the flat, vegetated area) viewed from a vantage point on a talus slope above the terrace. $B$, Riverward edge of a relict fluvial terrace (middle of image); this terrace has retreated far enough laterally to expose cross-bedded sandstone bedrock at river level. $C$, Relict fluvial terrace incised by a 10-meterwide arroyo (in foreground) that formed from erosion by overland flow. River is to the left. $D$, Archaeological feature (a charcoal hearth) exposed in the wall of an arroyo. The arroyo incised through a terrace composed of interbedded Colorado River fluvial sediment and locally derived slopewash material. Arroyo wall is approximately 1.5 meters high at this location; hearth is located approximately 0.5 meters below the ground surface. $E, A$ rare modern fluvial sandbar along the Colorado River margin in February 2013, three months after a controlled flood deposited the sandbar. Note tamarisk trees at landward margin of the sandbar. Riparian vegetation is nearly ubiquitous in Glen Canyon and reduces the potential for aeolian sand transport from fluvial sandbars to most inland areas. F, Sedimentary structures exposed in an arroyo wall (same arroyo as in $D$ ) are diagnostic of fluvial deposition. These fluvial climbing ripples (Rubin and Carter, 2006) show soft-sediment deformation structures (fluid-escape structures, in upper third of image) that commonly result from rapid deposition during a sediment-rich flow event. The presence of these structures within the majority of the terrace thickness indicates that the sediment originated from Colorado River floods. Pencil shown for scale. G, Aeolian sand transport on a windy day in February 2016; the transport direction was from left to right, moving sand upward along a large sand ramp feature that spans from river mile -1.4 to -2.1. Colorado River is in foreground. Suspended-sand transport is visible to a height of approximately 80 meters above the ground surface. $H$, Adjacent areas of aeolian sand deposition (in background, behind dashed line) and aeolian erosion (foreground, in front of dashed line). Wind ripples on the surface of the background sediment indicate recent aeolian sand activity; tan color of recently transported sand implies some derivation from local bedrock sources in addition to Colorado River sediment. Cohesive, beige-gray sediment in foreground displays (upon examination at closer scales than shown in photograph) exposed fluvial climbing ripple structures similar to those in F and local "blowout" morphology, indicating that wind erosion sculpted the surface of this relict fluvial deposit. 

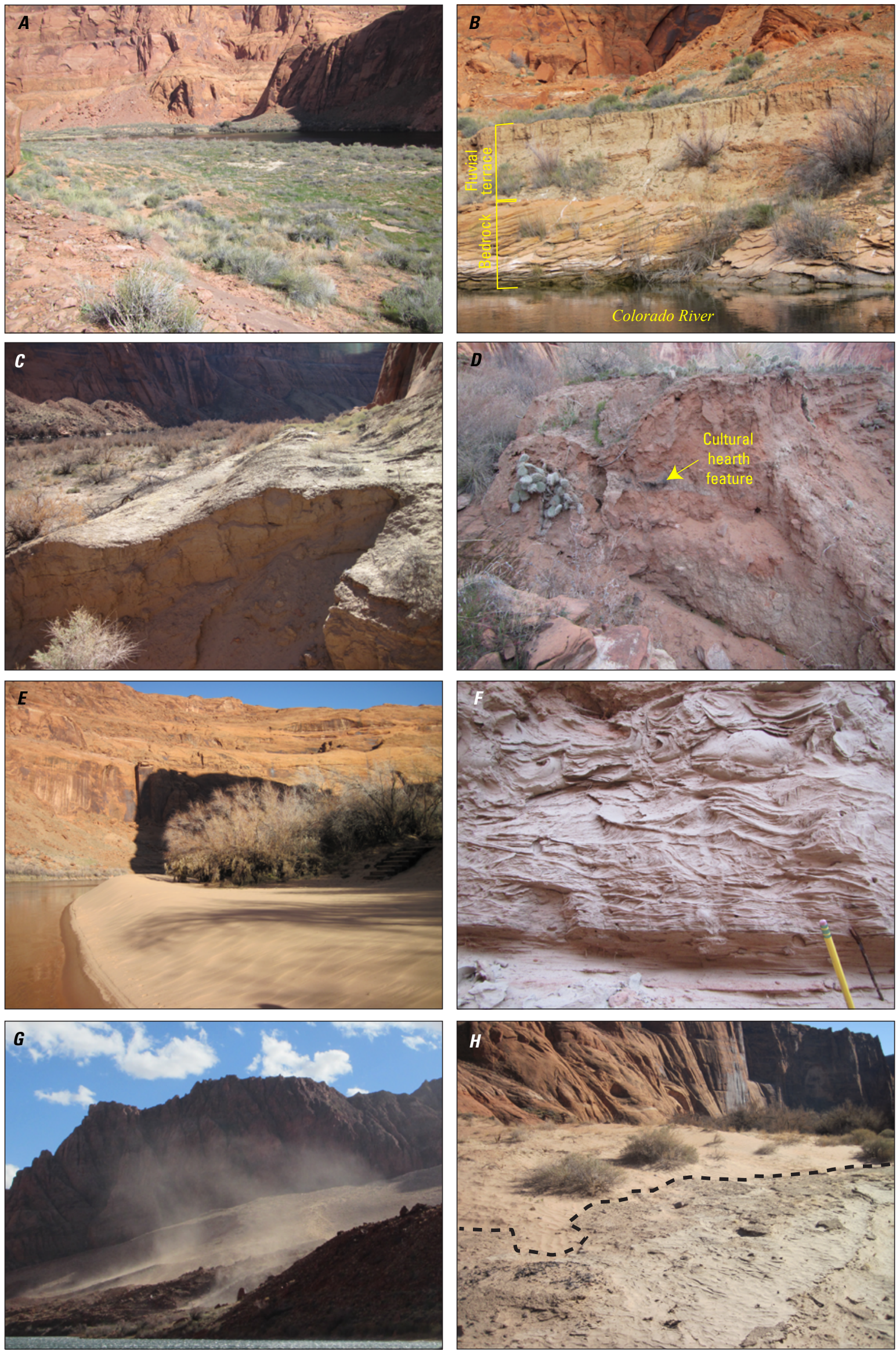
flows, sediment evacuation rates decreased substantially, but because the Paria River - a major sediment-supplying tributary of the Colorado River - enters the river downstream from Glen Canyon (at Lees Ferry, RM 0), the Glen Canyon reach continues to be more sediment-deficient today than Marble and Grand Canyons. This sediment deficit and associated grain-size winnowing (coarsening in the absence of fine sediment supply) caused some of the former fluvial sandbars in the active river channel to transition to gravel deposits. The riverbed grain size in Glen Canyon has coarsened overall from sand-sized to pebble-cobble-sized since the 1950s (Grams and others, 2007).

The proportion of sand that is currently active with respect to aeolian sand transport - that is, showing evidence for recent aeolian sand movement including wind ripples, pronounced dune crests, and dune slip faces at the angle of repose (Lancaster, 1994, 1995) - is low in Glen Canyon, consistent with the lack of fluvial sandbars and other unvegetated sand areas that could supply aeolian sand to upland landscapes (Sankey and Draut, 2014; East and others, 2016). Of the sand area that East and others (2016) mapped above the $1,270 \mathrm{~m}^{3} / \mathrm{s}$ stage between RM -13 and -6 , only 1.3 percent was found to be "open" or active with respect to aeolian transport; the rest was covered with biologic soil crust and vegetation, indicating a lack of recent aeolian sand movement or new sand deposition. In contrast, reaches studied in Marble Canyon and Grand Canyon, where modern sand supply is greater and aeolian dunes commonly form just downwind of eddycaptured sandbars, show recent aeolian sand activity over 5-35 percent of the total sand area (East and others, 2016).

Aeolian dune morphology is rare in Glen Canyon, despite fluvial terraces containing ample sediment to form dunes. Well defined aeolian dunes occur at RM -10.6 and a large sand ramp is present near RM -2 (fig. 2G), but aeolian landforms are otherwise uncommon in Glen Canyon. Wind strength and sediment grain size on Glen Canyon terraces are similar to places studied in Marble and Grand Canyons where aeolian dunes are present (East and others, 2016). The general rarity of aeolian dunes in Glen Canyon suggests that aeolian sand transport may not have been particularly important to landscape evolution and archaeological site preservation in this reach of the river even before dam construction; local wind dynamics (zones of airflow convergence) simply may not have been sufficiently conducive to aeolian sand accumulation or retention to allow dunes to form. Local wind dynamics determine whether sand flux will be net-erosional or netdepositional at any particular location. Examples of wind scour eroding sediment from pre-dam fluvial terraces in Glen Canyon, most notably around RM -11.5 (fig. $2 H$ ), suggest that locally erosive wind dynamics may have prevailed locally. Thus, the potential for archaeological site preservation by aeolian sediment transport in the past (or present and future) appears lower in Glen Canyon than for many areas of the river corridor in Marble Canyon and Grand Canyon, where aeolian sand deposition is commonly important to archaeological site preservation (Fairley, 2005; Draut and Rubin, 2008; East and others, 2016).
The Glen Canyon reach appears especially vulnerable to erosion by rills, gullies, and arroyos; Glen Canyon sedimentary terraces have more drainage area per unit sand area than do reaches downstream from Lees Ferry (Sankey and Draut, 2014) and drainages have grown large enough in some places to incise fluvial terraces to bedrock, degrading and removing archaeological material in the process (Anderson and others, 2006; fig. 2B-D). High-resolution light detection and ranging (lidar) measurements of topographic change at several Glen Canyon archaeological sites show that, although rates of sediment removal by erosive processes (aeolian deflation and overland flow) in Glen Canyon are similar to rates in Marble and Grand Canyons, the lack of compensatory aeolian deposition in Glen Canyon means that net erosion rates are greater there (East and others, 2016). These recent findings are consistent with the disconnected nature of Glen Canyon upland landscapes from modern sediment supply; there is extremely low potential for aeolian sand supply to anneal drainages at any location in Glen Canyon (East and others, 2016, and this study). The greater prevalence of rills, gullies, and arroyos in Glen Canyon than in much of Marble and Grand Canyon is attributable both to the inherent geomorphic context, which promoted formation of extensive and thick fluvial terraces but precluded formation of eddy sandbars that could act as aeolian sand sources, and to cumulative and pronounced effects of postdam environmental changes (including sediment-supply deficit, riparian vegetation expansion, and local base-level lowering).

One other contemporary driver of environmental change that is ongoing in Glen Canyon is the herbivory of riparian tamarisk shrubs and trees by the tamarisk beetle (Sankey and others, 2016). The tamarisk beetle arrived in Glen Canyon in 2009. Herbivory can result in defoliation of tamarisk during the growing season when canopies are otherwise leafed-out, green, and photosynthetically active (Sankey and others, 2016). Remote-sensing analysis of aerial imagery acquired in May 2013 determined that approximately one quarter of all tamarisk shrub canopies were defoliated to some extent within a 5-hectare study area of the Glen Canyon riparian zone (Sankey and others, 2016). Increased herbivory could lead to greater mortality of tamarisk in Glen Canyon in the future. Although woody riparian vegetation presently inhibits connectivity of sediment between fluvial sandbars (aeolian sand sources) and archaeological sites (East and others, 2016), it is currently unclear how any future loss of Glen Canyon riparian vegetation could affect sand redistribution, given the general modern sediment deficiency in this part of the river corridor.

\section{Objectives and Evaluation Criteria}

Recognizing the pronounced vulnerability of Glen Canyon depositional landscapes - and the archaeological sites within them - to gully erosion in combination with the low potential for aeolian sediment deposition, we evaluated relevant 
geomorphic characteristics of individual archaeological sites in the Glen Canyon reach. In this study, we build on earlier geomorphic and geoarchaeological investigations of cultural sites and their landscape context (Anderson and others, 2006; Spurr and Colette, 2007; Pederson and others, 2011; Collins and others, 2014; East and others, 2016) to assess the landscape processes at 54 documented archaeological sites in Glen Canyon between RM -15 and 1.3 (that is, from Glen Canyon Dam, at RM -15, to 1.3 miles downstream of Lees Ferry). Our objectives are to provide field-based criteria to demonstrate each site's potential to receive aeolian sediment and to assess the development of erosive drainage networks. To achieve these objectives, we not only assessed sites during field work in 2016, but also extend our observations back six decades by analyzing aerial photographic imagery where sufficient coverage is available. These assessments address river-corridor and cultural-resource management objectives to determine (1) the number and proportion of archaeological sites in the Colorado River corridor that potentially receive aeolian sand as a result of controlled floods, which determine the modern fluvial sandbar extent; and (2) whether archaeological sites erode or change faster or in a significantly different manner than they would if the dam were operated differently.

We completed two complementary geomorphic site classifications at 54 archaeological sites in Glen Canyon and uppermost Marble Canyon. Most of those sites were last assessed by Spurr and Collette (2007). These locations comprised 53 individual sites; we considered one site as two separate localities on opposite river banks because the geomorphic settings of the two localities differ substantially. Site locations are not shown because they are confidential.

We used one classification system to evaluate the potential for aeolian transport of fluvially sourced sand from the active river channel to higher elevation sites - referred to as the aeolian classification system (East and others, 2016). We developed a second classification system to identify whether rills, gullies, or arroyos (water flow paths or drainages) exist within or adjacent to an archaeological site - referred to as the drainage classification system (Hereford and others, 1993; Leap and others, 2000). This classification system also identifies the general geomorphic surface, and thus the effective base level, to which those overland-flow paths drain.

We apply the aeolian classification system in the same manner that it has previously been applied to 358 archaeological sites in the Colorado River corridor within Grand Canyon National Park (East and others, 2016). At each of the 54 Glen Canyon locations, we document the (1) geomorphic and sedimentary context at each site (whether fluvial, aeolian, or other), (2) dominant wind direction, (3) presence of a modern fluvial sand deposit upwind of the site (assessed for each time step independently), and (4) presence of vegetation or topographic barriers between the fluvial deposit and downwind archaeological site (see East and others (2016) for more details). These metrics define five types of archaeological sites (table 1, fig. 3). Types 1-4 define those whose geomorphic context includes river-derived sand as an integral component — either fluvial, aeolian, or both. Type 5 defines those at which river-derived sand is absent or, if present, is incidental to the geomorphic context.

We defined type 1 archaeological sites to have the greatest potential to receive aeolian sand from modern fluvial sandbars and defined a decreasing potential in order from type 2 through 4. At type 5 sites aeolian sand deposition may occur, but is irrelevant to the geomorphic context of the archaeological material. Although we used the same classification system that East and others (2016) applied to Marble and Grand Canyon sites, the geomorphic differences between those landscapes and the Glen Canyon reach affect the application of the classification system in Glen Canyon. In contrast to Marble and Grand Canyons, aeolian processes are only geomorphically relevant (that is, forming obvious dune features) in a few

Table 1. Classification of archaeological sites based on potential aeolian sand supply. This table provides a summary of the aeolian classification system. For a more detailed explanation see East and others (2016).

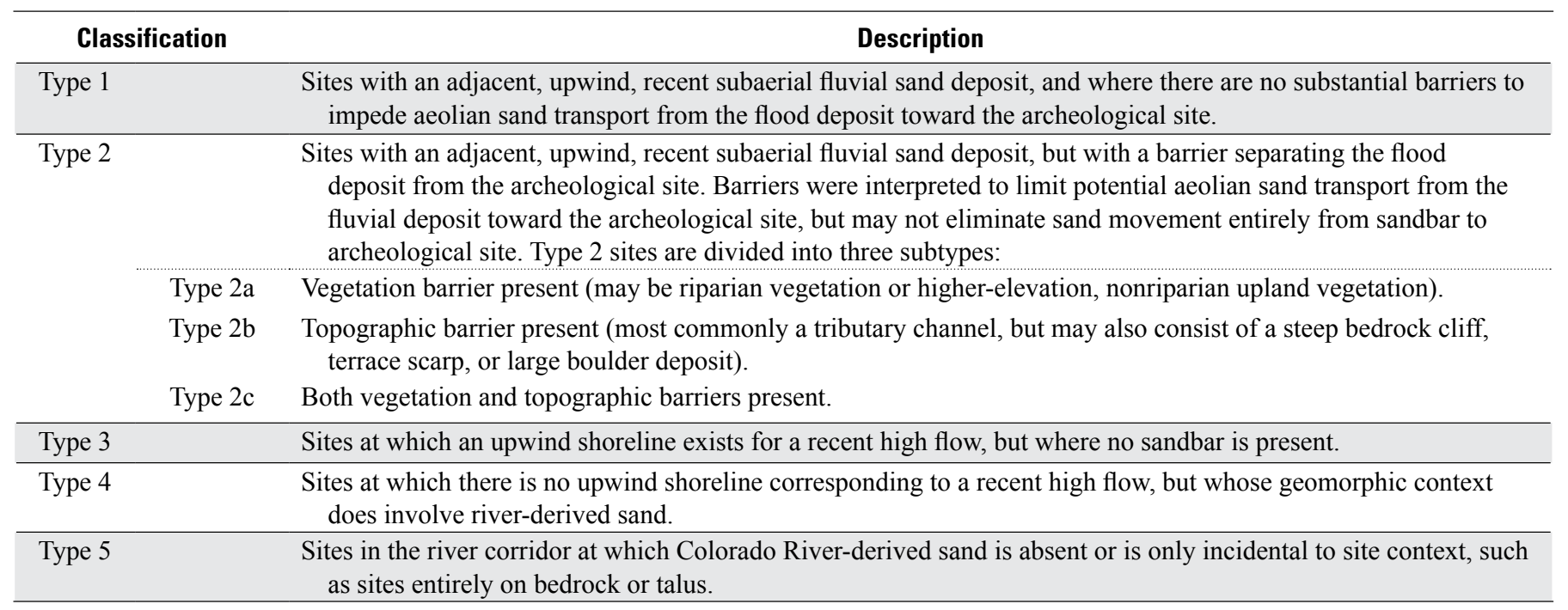



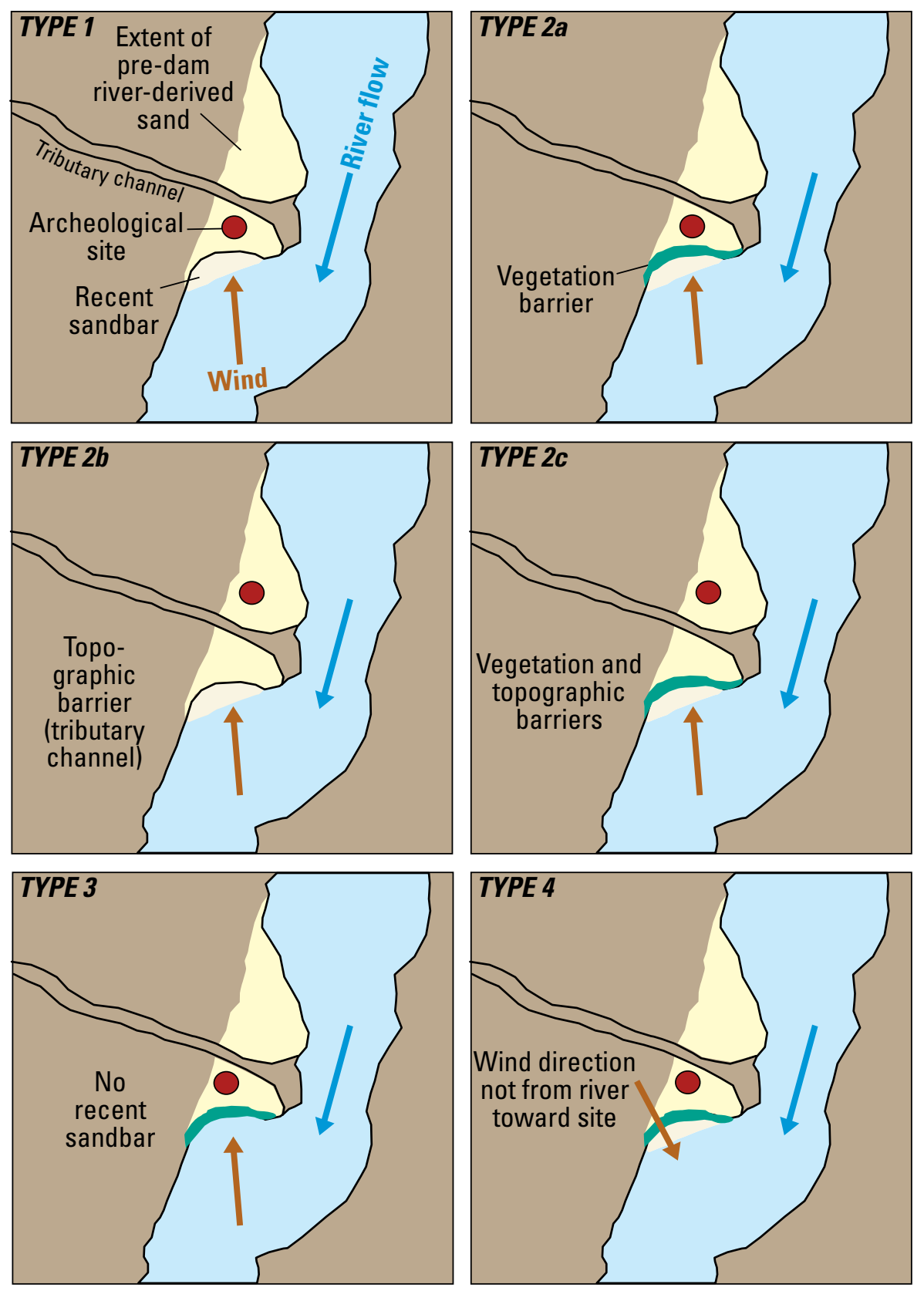

Figure 3. Schematic diagram illustrating the classification system used to identify potential sources of aeolian sand that could reach archaeological sites. See table 1 for descriptions of each classification type. Modified from figure 9 of East and others (2016). locations in Glen Canyon. At most type 3 sites in Grand Canyon a geomorphically significant process - aeolian sand delivery to an aeolian dune field containing the archaeological site - was recently truncated by sandbar loss (either by erosion or vegetation overgrowth). In Glen Canyon, however, the loss of a pre-existing sandbar at a type 3 site may have little or no geomorphic significance for a downwind archaeological site because any aeolian dunes there did not depend on the lost sandbar for its sediment supply. Rather than being shaped substantially by aeolian supply and wind-reworking, the Glen Canyon sedimentary deposits relied almost exclusively on deposition from large floods. Nevertheless, we conducted this assessment to evaluate whether any sites exhibit the potential to receive sand supply in the modern dam-controlled era, as well as to examine changes in sandbar presence, riparian vegetation, and potential sand-transport pathways in the past using aerial photographic records.

We used the drainage classification system, developed by Hereford and others (1993) and adapted by Leap and others (2000), to identify whether drainages exist at each site that contribute to sediment erosion by overland flow, and, if drainages exist, whether they are integrated with the active river channel or another geomorphic surface (table 2, fig. 4). Drainage classification was completed for 241 Grand Canyon 
Table 2. Classification of archaeological sites based on overland-flow drainage setting. This table provides a summary of the drainage classification system. For a detailed explanation see Leap and others (2000); to make the numeric system more intuitive, drainage types are renumbered from Leap and others (2000).

\begin{tabular}{ll}
\hline Classification & \multicolumn{1}{c}{ Description } \\
\hline Type 1 & Sites are not dissected by rills, gullies, or arroyos. \\
Type 2 & $\begin{array}{c}\text { Terrace-based drainages: Sites are dissected by rills, gullies, and (or) arroyos that grade to a terrace surface that is higher in elevation } \\
\text { than the active river. }\end{array}$ \\
Type 3 & $\begin{array}{l}\text { Side-canyon-based drainages: Sites are dissected by rills, gullies, and (or) arroyos that grade to a tributary of the Colorado River. } \\
\text { Type } 4\end{array}$ \\
\hline
\end{tabular}

Type 1: No drainage

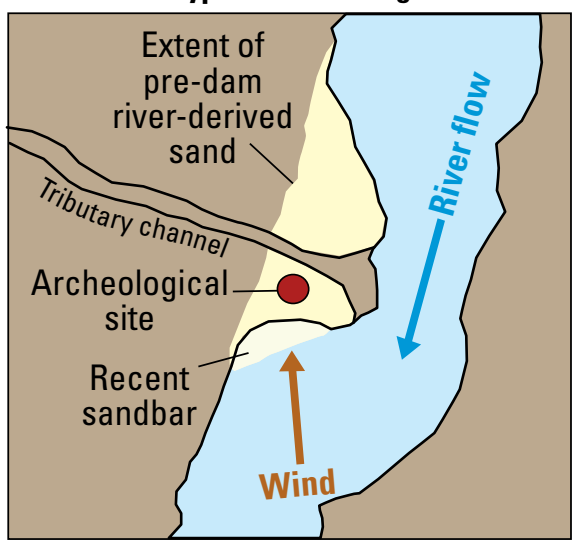

Type 3: Side-canyon-based drainage

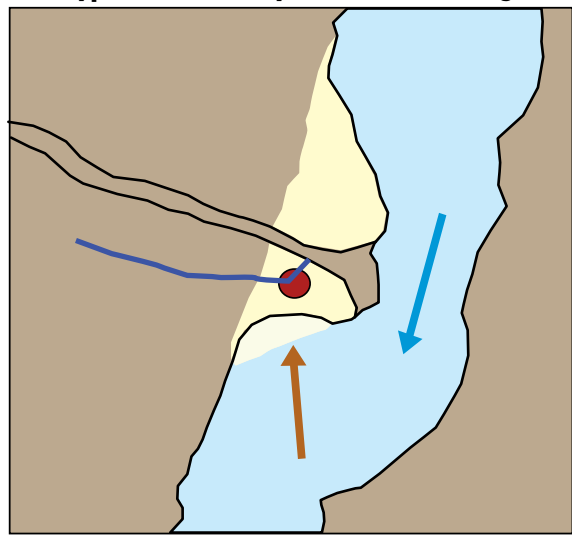

Type 2: Terrace-based drainage

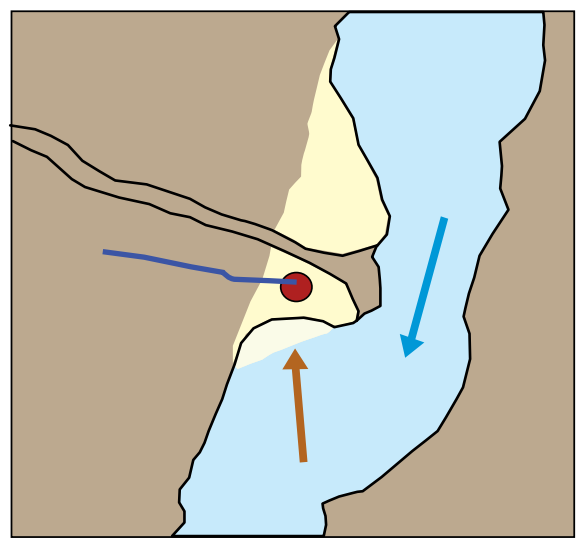

Type 4: River-based drainage

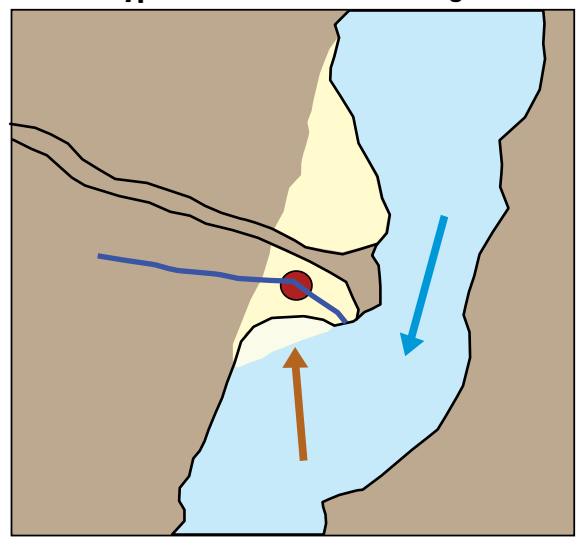

Figure 4. Schematic diagram illustrating the classification system used to identify overland-flow drainage erosion affecting archaeological sites. See table 2 for a description of each classification type. sites by Leap and others (2000) and those classifications were updated in 2016 and 2017, and are still in progress. In Glen Canyon, we evaluated drainage channels (rills, gullies, and arroyos, in order of increasing size) at each of the 54 archaeological sites by noting whether such drainage systems are present at or adjacent to each site. We also documented the downslope extent of the drainage- that is, the base level to which each drainage grades. We binned each site into one of four categories: no drainages, terrace-based drainages, side-canyon-based drainages, or river-based drainages (table 2; fig. 4). This classification is meant to assess the maximum local maturity of drainage networks at a snapshot in time for each field visit or set of aerial photographs. Thus, river-based and side-canyon-based drainages are graded to the lowest possible base level in this system because they represent the evolutionary endpoint of drainage development. Terrace-based drainages, on the other hand, represent an intermediary stage of development and may, in the future, become river-based or side-canyonbased drainages.

The aeolian and drainage classifications cannot, by themselves, be used to monitor how sediment supply or loss affect the evolution of a particular landscape or cultural site over time. Rather, to quantify the progression of sediment deposition or erosion through time, changes in surface 
elevation would need to be measured using topographic survey techniques, such as lidar (for example, Collins and others, 2014).

\section{Methods}

We applied the aeolian and drainage classifications (tables 1, 2; figs. 3, 4) to each of the 54 study sites using direct field observations and we extended the evaluations into the past by analyzing historical aerial photographs. We focused on five discrete time steps.

1. February 2016-This field study followed three recent controlled floods (in 2012, 2013, and 2014). Each of those controlled floods lasted three days with discharges above $1,000 \mathrm{~m}^{3} / \mathrm{s}$. Flows during our field observations ranged from approximately 240 to $410 \mathrm{~m}^{3} / \mathrm{s}$ owing to daily dam-controlled fluctuations. For approximately 20 sites where field visits were not possible in February 2016, our evaluations were based on May 2013 aerial imagery (Durning and others, 2016), which was collected 6 months after the November 2012 controlled flood.

2. March 1996-We analyzed black-and-white aerial photographs that were taken at a flow of $226 \mathrm{~m}^{3} / \mathrm{s}$ two weeks after a 7-day controlled flood of 1,300 $\mathrm{m}^{3} / \mathrm{s}$.

3. October 1984-We analyzed black-and-white aerial photographs taken after dam-released floods on the mainstem Colorado River in 1983 and 1984 caused by large spring snowmelt runoff, which had an instantaneous peak discharge of 2,740 $\mathrm{m}^{3} / \mathrm{s}$ in 1983 (maximum daily average discharge was $2,610 \mathrm{~m}^{3} / \mathrm{s}$ on June 29,1983 ). Flows were above $1,000 \mathrm{~m}^{3} / \mathrm{s}$ continuously for several months each in 1983, 1984, and 1985 (U.S. Geological Survey, 2017). The October 1984 aerial photographs were taken at a discharge of approximately $140 \mathrm{~m}^{3} / \mathrm{s}$.

4. June 1973-Black-and-white aerial photographs of the Lees Ferry area, which were taken with discharge rates ranging from 170 to $368 \mathrm{~m}^{3} / \mathrm{s}$, show the river corridor downstream of RM -0.3 . High flows preceding the June 1973 imagery include several years during which daily average discharge exceeded $1,000 \mathrm{~m}^{3} / \mathrm{s}$ for weeks to months and several larger pre-dam flow peaks, including $3,453 \mathrm{~m}^{3} / \mathrm{s}$ in $1952,3,566 \mathrm{~m}^{3} / \mathrm{s}$ in 1957 , and $2,989 \mathrm{~m}^{3} / \mathrm{s}$ in 1958 (Topping and others, 2003; U.S. Geological Survey, 2017).

5. September 1952-Black-and-white aerial photographs cover the river corridor from the Glen Canyon Dam site to Lees Ferry before dam construction commenced. These images were taken at a discharge rate of $200 \mathrm{~m}^{3} / \mathrm{s}$. The spring flood of 1952 peaked at $3,453 \mathrm{~m}^{3} / \mathrm{s}$ in midJune of that year (U.S. Geological Survey, 2017).
Thus, the 1952 photographs allow us to evaluate sand sources from a natural spring flood and one that was much larger than any post-dam flows have been. The 1973 and 1984 photographs permit interpretation of fluvial sand sources that formed from a variety of flows that exceeded the range of normal dam operations, but were not an isolated controlled-flood event. The 1996 photographs and 2016 field work allow us to evaluate potential aeolian sand supply shortly after individual, discrete controlled-flood events of similar magnitude enlarged fluvial sandbars.

The role of daily flow fluctuations differed between the pre-dam 1952 photographs (and the geomorphic conditions that they represent) and post-dam time, and that difference affected our analysis. Daily flow fluctuations in the pre-dam era were negligible on most days and, when they did occur, commonly occurred with smaller magnitudes and with greater irregularity compared to the dam-controlled hydrograph; pre-dam daily flows occasionally varied by more than an order of magnitude. This difference in the daily flow-fluctuation regime led us to adopt different assumptions for pre- and post-dam low-elevation fluvial sand deposits. In post-dam images, both for this report and when classifying sites in Grand Canyon National Park (East and others, 2016), we considered damp, low-elevation fluvial sandbars not to be viable aeolian sand sources. We made this assumption because post-dam daily flow fluctuations inundate sand deposits. Daily inundation commonly leads to sandbar erosion over subsequent weeks and months, and does not allow the remaining sand time to dry out enough to be mobilized by wind (wind cannot entrain and transport wet sand). Thus, if a post-dam aerial photograph showed a shoreline fronted by wet, low-elevation fluvial sand but no subaerial, unvegetated sand, we would classify a downwind archaeological site as type 3 . However, when analyzing predam (1952) photographs we assumed that damp or partially submerged sandbars could become viable aeolian sand sources, given the typical pre-dam flow regime. Colorado River flows rarely featured substantial day-to-day fluctuations in the fall of 1952. The daily average discharge decreased from $200 \mathrm{~m}^{3} / \mathrm{s}$ (when aerial photographs were taken in mid-September) to values around $153 \mathrm{~m}^{3} / \mathrm{s}$ during several weeks in mid to late October. Flow rates remained at or below $200 \mathrm{~m}^{3} / \mathrm{s}$ for two months after the September 1952 aerial images were taken (data from U.S. Geological Survey (USGS) gaging station 09380000, Colorado River at Lees Ferry; U.S. Geological Survey, 2017). We judged that the flows below $200 \mathrm{~m}^{3} / \mathrm{s}$ likely would have allowed sandbars that were subaerial but damp to dry out and become viable aeolian sand sources throughout most of the fall and winter of 1952-1953. Therefore, in cases where the 1952 images showed a shoreline fronted by damp, subaerial fluvial sandbars, we classified downwind sites as type 1 or 2 , depending on whether vegetation or topographic barriers existed.

We assessed locally dominant wind directions from direct measurements, where possible, using data from two weather stations operated in the river corridor by the USGS Grand Canyon Monitoring and Research Center at RM -11.2 and RM 0.5 (Caster and others, 2014; Caster and Sankey, 2016). If no weather station operated near a particular area of interest, we inferred the local prevailing wind direction from 
orientations of aeolian dune crests and slip faces, orientations of sand shadows that form in the lee of rocks and vegetation, and orientations of wind ripples. These geomorphic features, if clearly visible in the field, reliably indicate the dominant directions of winds strong enough to transport sediment (for example, Lancaster, 1994, 1995). Dune crests, slip faces, and large sand shadows are persistent features that tend to form over time scales longer than one wind event or season. Where neither direct wind measurements nor clear geomorphic indicators of wind direction were present, we assumed that the local prevailing wind direction would be toward upstream. We made this assumption because the dominant wind direction in parts of the river corridor oriented northeast-southwest is generally upstream (toward the northeast) owing to atmospheric circulation and elevation-induced pressure differences. Side canyon confluences and reaches with major changes in canyon orientation, however, can have locally variable wind direction (East and others, 2016). We also assume that the wind direction as determined in 2016 has been constant since 1952. That assumption is based on measurements of dominant wind directions at several locations in Marble and Grand Canyons that have shown consistent prevailing wind directions spanning more than a decade (2003-2017; Draut and Rubin, 2008; Caster and others, 2014; Caster and Sankey, 2016).

Our evaluation of geomorphic context for many of the sites included inferences about whether sediment was dominantly derived from the Colorado River (the large upstream watershed) or from local sources, derived from sandstone bedrock or colluvium deposited by slopewash or colluvial processes. This inference relies on differences in color and grain size; we assume that the river-derived (fluvial and aeolian) sediment in this system is distinctly lighter colored, finer grained, and better sorted than the locally derived material. With respect to color, Colorado River sediment generally falls within the range of $7.5 \mathrm{YR}(8 / 3-8 / 4)$ to 10YR (8/2-8.5/2) in the 2009 Munsell soil color chart, whereas slopewash and colluvial sediment in Glen Canyon is variable but most commonly in the range of $10 \mathrm{R}(6 / 6-4 / 8)$ to $2.5 \mathrm{YR}(5 / 6-4 / 8)$.

At each archaeological site that we visited in the field, we identified the number of rills, gullies, and arroyos currently present. We define rills as drainage paths with width and (or) depth $<5$ centimeters $(\mathrm{cm})$ and length $<10 \mathrm{~m}$, gullies as drainage paths with width and (or) depth between $5 \mathrm{~cm}$ and $10 \mathrm{~m}$ and length $>10 \mathrm{~m}$, and arroyos as drainage paths with width and (or) depth $>10 \mathrm{~m}$ and length $>10 \mathrm{~m}$. We noted where each drainage path originated relative to the boundary of the site, that is, upslope, within the site, or downslope. Drainages originating downslope of the site boundary could become relevant to the site condition if flow paths incise headward into the site. We noted where each drainage path terminated relative to the site boundary and also noted whether the drainage was graded to the contemporary active river channel, to a side-canyon tributary channel, or to a sedimentary terrace or other surface above the river or tributary channels. If sites had multiple drainage paths terminating on different geomorphic surfaces, it is possible that they could meet the definition of more than one drainage class. In such instances, sites were classified as type 4 if they contained river-based drainage(s), even if they also contained side-canyon-based (type 3) and (or) terrace-based (type 2) drainages. Sites were classified as type 3 if they contained side-canyon-based drainages but no river-based drainages, even if they also contained terrace-based drainages. Sites were classified as type 2 only if they contained terrace-based drainages but contained no other types of drainages. Sites were classified as type 1 if they contained no drainages of any kind (fig. 4). Thus, our classification designates the maximum local maturity level for drainages at each site, assigning the site the drainage class of the most mature drainage present. That is, if a site contained both a type 4 drainage and also a type 2 gully that had not yet integrated with the type 4 drainage, we assigned the site to drainage type 4 .

The boundary of each site was interpreted from a geographic information system (GIS) polygon overlaid on recent aerial imagery (acquired in May 2013) in field map books. In some instances, we followed Glen Canyon National Recreation Area archaeology staff recommendations to evaluate an area larger than the mapped site boundary owing to recent observations of archaeological materials outside the site boundary. We note in the classification results the specific instances where the extended site areas are evaluated (discussed in a confidential appendix provided to the National Park Service). Some sites could not be visited in the field owing to the need to protect sensitive site areas or because additional permitting was required for direct site visits. In such instances, at approximately 15 sites, we evaluated the site using binoculars from either river level (on a boat) or across the river, or we interpreted 2013 aerial photographs. We note in the appendix the sites we did not visit directly in 2016.

\section{Results}

The results of the classification analysis are summarized in table 3 and plotted in figures 5 and 6 . We find that the 54 river-corridor archaeological sites studied here show substantial changes over the past several decades with regard to their potential to receive aeolian sand sourced from fluvial sandbars (fig. 5; table 3). Most notably, the number of type 1 and type 2 sites has decreased dramatically since 1952 and corresponds to an increase in the number of type 3 sites. This change was especially prominent between the 1952 predam photographs and those from the post-dam era (fig. 5). Even within the post-dam era, the number of type 3 sites has increased substantially. Over the two decades between 1996 and 2016, the number of type 3 sites increased by nearly 50 percent (fig. 5). Because 37 sites were not included in the 1973 aerial photograph extent, and thus could not be classified for that year (fig. 5), we could make only limited comparisons between 1952 and 1973 or between 1973 and 1984.

In contrast to the marked changes over the past six decades with regard to the availability of aeolian sand supply (fig. 5), the types of drainages at the archaeological sites have changed little since 1984 (fig. 6; tables 3, 4). However, this result is based on limited data because we were unable to classify 


\section{Modern Landscape Processes Affecting Archaeological Sites along the Colorado River Corridor, Arizona}

Table 3. Results of the potential aeolian sand supply and drainage classification analysis for 54 archaeological sites in Glen Canyon and uppermost Marble Canyon.

\begin{tabular}{|c|c|c|c|c|c|c|}
\hline Site number & 1952 & 1973 & 1984 & 1996 & 2016 & Classification \\
\hline \multirow{2}{*}{ C:03:0010 } & 3 & $\mathrm{~N} / \mathrm{C}$ & $2 a$ & $2 \mathrm{a}$ & 3 & Aeolian \\
\hline & 4 & $\mathrm{~N} / \mathrm{C}$ & 4 & 4 & 4 & Drainage \\
\hline \multirow[t]{2}{*}{ C:03:0006 } & 5 & $\mathrm{~N} / \mathrm{C}$ & 5 & 5 & 5 & Aeolian \\
\hline & $\mathrm{N} / \mathrm{C}$ & $\mathrm{N} / \mathrm{C}$ & $\mathrm{N} / \mathrm{C}$ & $\mathrm{N} / \mathrm{C}$ & $\mathrm{N} / \mathrm{C}$ & Drainage \\
\hline \multirow[t]{2}{*}{ C:03:0004 } & 5 & $\mathrm{~N} / \mathrm{C}$ & 5 & 5 & 5 & Aeolian \\
\hline & $\mathrm{N} / \mathrm{C}$ & $\mathrm{N} / \mathrm{C}$ & $\mathrm{N} / \mathrm{C}$ & $\mathrm{N} / \mathrm{C}$ & $\mathrm{N} / \mathrm{C}$ & Drainage \\
\hline \multirow[t]{2}{*}{ C:02:0036 } & 3 & $\mathrm{~N} / \mathrm{C}$ & 3 & 3 & 3 & Aeolian \\
\hline & 4 & $\mathrm{~N} / \mathrm{C}$ & 4 & 4 & 4 & Drainage \\
\hline \multirow[t]{2}{*}{ C:02:0073 } & 5 & $\mathrm{~N} / \mathrm{C}$ & 5 & 5 & 5 & Aeolian \\
\hline & $\mathrm{N} / \mathrm{C}$ & $\mathrm{N} / \mathrm{C}$ & $\mathrm{N} / \mathrm{C}$ & $\mathrm{N} / \mathrm{C}$ & $\mathrm{N} / \mathrm{C}$ & Drainage \\
\hline \multirow[t]{2}{*}{ C:02:0071 } & 3 & $\mathrm{~N} / \mathrm{C}$ & $2 \mathrm{c}$ & $2 \mathrm{c}$ & $2 c$ & Aeolian \\
\hline & $\mathrm{N} / \mathrm{C}$ & $\mathrm{N} / \mathrm{C}$ & 2 & 2 & 2 & Drainage \\
\hline \multirow[t]{2}{*}{ C:02:0077 } & 3 & $\mathrm{~N} / \mathrm{C}$ & $2 c$ & $2 c$ & $2 c$ & Aeolian \\
\hline & $\mathrm{N} / \mathrm{C}$ & $\mathrm{N} / \mathrm{C}$ & 2 & 2 & 2 & Drainage \\
\hline \multirow[t]{2}{*}{ C:02:0075 } & $2 \mathrm{c}$ & $\mathrm{N} / \mathrm{C}$ & 3 & 3 & 3 & Aeolian \\
\hline & $\mathrm{N} / \mathrm{C}$ & $\mathrm{N} / \mathrm{C}$ & 4 & 4 & 4 & Drainage \\
\hline \multirow[t]{2}{*}{ C:02:0079 } & 5 & $\mathrm{~N} / \mathrm{C}$ & 5 & 5 & 5 & Aeolian \\
\hline & $\mathrm{N} / \mathrm{C}$ & $\mathrm{N} / \mathrm{C}$ & 4 & 4 & 4 & Drainage \\
\hline \multirow[t]{2}{*}{ C:02:0037 } & 1 & $\mathrm{~N} / \mathrm{C}$ & $2 \mathrm{c}$ & $2 c$ & 3 & Aeolian \\
\hline & 4 & $\mathrm{~N} / \mathrm{C}$ & 4 & 4 & 4 & Drainage \\
\hline \multirow[t]{2}{*}{ C:02:0103 } & 5 & $\mathrm{~N} / \mathrm{C}$ & 5 & 5 & 5 & Aeolian \\
\hline & $\mathrm{N} / \mathrm{C}$ & $\mathrm{N} / \mathrm{C}$ & $\mathrm{N} / \mathrm{C}$ & $\mathrm{N} / \mathrm{C}$ & $\mathrm{N} / \mathrm{C}$ & Drainage \\
\hline \multirow[t]{2}{*}{ C:02:0081 } & $2 \mathrm{c}$ & $\mathrm{N} / \mathrm{C}$ & $2 \mathrm{c}$ & $2 \mathrm{c}$ & 3 & Aeolian \\
\hline & $\mathrm{N} / \mathrm{C}$ & $\mathrm{N} / \mathrm{C}$ & 2 & 2 & 2 & Drainage \\
\hline \multirow[t]{2}{*}{ C:02:0038 } & 5 & $\mathrm{~N} / \mathrm{C}$ & 5 & 5 & 5 & Aeolian \\
\hline & $\mathrm{N} / \mathrm{C}$ & $\mathrm{N} / \mathrm{C}$ & $\mathrm{N} / \mathrm{C}$ & $\mathrm{N} / \mathrm{C}$ & $\mathrm{N} / \mathrm{C}$ & Drainage \\
\hline \multirow[t]{2}{*}{ C:02:0032 } & $2 c$ & $\mathrm{~N} / \mathrm{C}$ & 3 & 3 & 3 & Aeolian \\
\hline & $\mathrm{N} / \mathrm{C}$ & $\mathrm{N} / \mathrm{C}$ & 4 & 4 & 4 & Drainage \\
\hline \multirow[t]{2}{*}{ C:02:0035 } & 3 & $\mathrm{~N} / \mathrm{C}$ & 3 & 3 & 3 & Aeolian \\
\hline & $\mathrm{N} / \mathrm{C}$ & $\mathrm{N} / \mathrm{C}$ & 4 & 4 & 4 & Drainage \\
\hline \multirow[t]{2}{*}{ C:02:0102 } & 5 & $\mathrm{~N} / \mathrm{C}$ & 5 & 5 & 5 & Aeolian \\
\hline & $\mathrm{N} / \mathrm{C}$ & $\mathrm{N} / \mathrm{C}$ & $\mathrm{N} / \mathrm{C}$ & $\mathrm{N} / \mathrm{C}$ & $\mathrm{N} / \mathrm{C}$ & Drainage \\
\hline \multirow[t]{2}{*}{ C:02:0039 } & 5 & $\mathrm{~N} / \mathrm{C}$ & 5 & 5 & 5 & Aeolian \\
\hline & 2 & $\mathrm{~N} / \mathrm{C}$ & 2 & 2 & 2 & Drainage \\
\hline \multirow[t]{2}{*}{ C:02:0074 } & 3 & $\mathrm{~N} / \mathrm{C}$ & $2 \mathrm{c}$ & $2 \mathrm{c}$ & 3 & Aeolian \\
\hline & 2 & $\mathrm{~N} / \mathrm{C}$ & 2 & 2 & 2 & Drainage \\
\hline \multirow[t]{2}{*}{ C:02:0078 } & 1 & $\mathrm{~N} / \mathrm{C}$ & 3 & 3 & 3 & Aeolian \\
\hline & 2 & $\mathrm{~N} / \mathrm{C}$ & 4 & 4 & 4 & Drainage \\
\hline \multirow[t]{2}{*}{ C:02:0087 } & 1 & $\mathrm{~N} / \mathrm{C}$ & $2 a$ & 3 & 3 & Aeolian \\
\hline & $\mathrm{N} / \mathrm{C}$ & $\mathrm{N} / \mathrm{C}$ & 2 & 2 & 2 & Drainage \\
\hline C:02:0091 & $2 c$ & $\mathrm{~N} / \mathrm{C}$ & 3 & 3 & 3 & Aeolian \\
\hline & 4 & $\mathrm{~N} / \mathrm{C}$ & 4 & 4 & 4 & Drainage \\
\hline Unassigned & 1 & $\mathrm{~N} / \mathrm{C}$ & 3 & 3 & 3 & Aeolian \\
\hline & $\mathrm{N} / \mathrm{C}$ & $\mathrm{N} / \mathrm{C}$ & $\mathrm{N} / \mathrm{C}$ & $\mathrm{N} / \mathrm{C}$ & $\mathrm{N} / \mathrm{C}$ & Drainage \\
\hline C:02:0076 & 3 & $\mathrm{~N} / \mathrm{C}$ & 3 & 3 & 3 & Aeolian \\
\hline & 3 & $\mathrm{~N} / \mathrm{C}$ & 3 & 3 & 3 & Drainage \\
\hline C:02:0040 & 5 & $\mathrm{~N} / \mathrm{C}$ & 5 & 5 & 5 & Aeolian \\
\hline & 4 & $\mathrm{~N} / \mathrm{C}$ & 4 & 4 & 4 & Drainage \\
\hline $\mathrm{C}: 02: 0080$ & 5 & $\mathrm{~N} / \mathrm{C}$ & 5 & 5 & 5 & Aeolian \\
\hline & $\mathrm{N} / \mathrm{C}$ & $\mathrm{N} / \mathrm{C}$ & 2 & 2 & 2 & Drainage \\
\hline
\end{tabular}


Table 3.-Continued

\begin{tabular}{|c|c|c|c|c|c|c|}
\hline Site number & 1952 & 1973 & 1984 & 1996 & 2016 & Classification \\
\hline \multirow[t]{2}{*}{ C:02:0084 } & $2 c$ & $\mathrm{~N} / \mathrm{C}$ & 3 & $2 \mathrm{c}$ & 3 & Aeolian \\
\hline & 2 & $\mathrm{~N} / \mathrm{C}$ & 2 & 2 & 2 & Drainage \\
\hline \multirow[t]{2}{*}{ C:02:0082 } & 5 & $\mathrm{~N} / \mathrm{C}$ & 5 & 5 & 5 & Aeolian \\
\hline & $\mathrm{N} / \mathrm{C}$ & $\mathrm{N} / \mathrm{C}$ & 1 & 1 & 1 & Drainage \\
\hline \multirow[t]{2}{*}{ C:02:0105 } & 5 & $\mathrm{~N} / \mathrm{C}$ & 5 & 5 & 5 & Aeolian \\
\hline & $\mathrm{N} / \mathrm{C}$ & $\mathrm{N} / \mathrm{C}$ & 4 & 4 & 4 & Drainage \\
\hline \multirow{2}{*}{$\mathrm{C}: 02: 0086$} & $2 \mathrm{c}$ & $\mathrm{N} / \mathrm{C}$ & $2 \mathrm{c}$ & $2 \mathrm{c}$ & 3 & Aeolian \\
\hline & 3 & $\mathrm{~N} / \mathrm{C}$ & 3 & 3 & 3 & Drainage \\
\hline \multirow[t]{2}{*}{ C:02:0013 } & $2 \mathrm{c}$ & $\mathrm{N} / \mathrm{C}$ & $2 \mathrm{c}$ & $2 \mathrm{c}$ & 3 & Aeolian \\
\hline & $\mathrm{N} / \mathrm{C}$ & $\mathrm{N} / \mathrm{C}$ & 1 & 1 & 3 & Drainage \\
\hline \multirow[t]{2}{*}{ C:02:0060 } & 1 & $\mathrm{~N} / \mathrm{C}$ & $2 \mathrm{a}$ & $2 \mathrm{a}$ & 3 & Aeolian \\
\hline & $\mathrm{N} / \mathrm{C}$ & $\mathrm{N} / \mathrm{C}$ & 3 & 3 & 3 & Drainage \\
\hline \multirow[t]{2}{*}{$\mathrm{C}: 02: 0090$} & 3 & $\mathrm{~N} / \mathrm{C}$ & $2 \mathrm{a}$ & $2 \mathrm{a}$ & 3 & Aeolian \\
\hline & $\mathrm{N} / \mathrm{C}$ & $\mathrm{N} / \mathrm{C}$ & 1 & 1 & 1 & Drainage \\
\hline \multirow[t]{2}{*}{ C:02:0108 } & 5 & $\mathrm{~N} / \mathrm{C}$ & 5 & 5 & 5 & Aeolian \\
\hline & $\mathrm{N} / \mathrm{C}$ & $\mathrm{N} / \mathrm{C}$ & $\mathrm{N} / \mathrm{C}$ & $\mathrm{N} / \mathrm{C}$ & $\mathrm{N} / \mathrm{C}$ & Drainage \\
\hline \multirow[t]{2}{*}{ C:02:0041 } & 5 & $\mathrm{~N} / \mathrm{C}$ & 5 & 5 & 5 & Aeolian \\
\hline & $\mathrm{N} / \mathrm{C}$ & $\mathrm{N} / \mathrm{C}$ & 1 & 1 & 1 & Drainage \\
\hline \multirow[t]{2}{*}{$\mathrm{C}: 02: 0088$} & 5 & $\mathrm{~N} / \mathrm{C}$ & 5 & 5 & 5 & Aeolian \\
\hline & 4 & $\mathrm{~N} / \mathrm{C}$ & 4 & 4 & 4 & Drainage \\
\hline \multirow[t]{2}{*}{ C:02:0058 } & $2 a$ & $\mathrm{~N} / \mathrm{C}$ & 3 & 3 & 3 & Aeolian \\
\hline & 4 & $\mathrm{~N} / \mathrm{C}$ & 4 & 4 & 4 & Drainage \\
\hline \multirow[t]{2}{*}{ C:02:0100 } & $2 a$ & $\mathrm{~N} / \mathrm{C}$ & $2 a$ & $2 \mathrm{a}$ & 3 & Aeolian \\
\hline & 4 & $\mathrm{~N} / \mathrm{C}$ & 4 & 4 & 4 & Drainage \\
\hline \multirow[t]{2}{*}{ C:02:0099 } & $2 \mathrm{a}$ & 3 & 3 & 3 & 3 & Aeolian \\
\hline & 2 & $\mathrm{~N} / \mathrm{C}$ & 2 & 2 & 2 & Drainage \\
\hline \multirow[t]{2}{*}{ C:02:0057 } & 4 & 4 & 4 & 4 & 4 & Aeolian \\
\hline & 4 & 4 & 4 & 4 & 4 & Drainage \\
\hline \multirow[t]{2}{*}{ C:02:0072 } & $2 \mathrm{a}$ & 3 & 3 & 3 & 3 & Aeolian \\
\hline & 4 & 4 & 4 & 4 & 4 & Drainage \\
\hline \multirow[t]{2}{*}{$\mathrm{C}: 02: 0011$} & $2 a$ & 3 & 3 & 3 & 3 & Aeolian \\
\hline & 4 & 4 & 4 & 4 & 4 & Drainage \\
\hline \multirow[t]{2}{*}{$\mathrm{C}: 02: 0056$} & 5 & 5 & 5 & 5 & 5 & Aeolian \\
\hline & $\mathrm{N} / \mathrm{C}$ & $\mathrm{N} / \mathrm{C}$ & $\mathrm{N} / \mathrm{C}$ & $\mathrm{N} / \mathrm{C}$ & $\mathrm{N} / \mathrm{C}$ & Drainage \\
\hline \multirow[t]{2}{*}{ C:02:0104 } & 5 & 5 & 5 & 5 & 5 & Aeolian \\
\hline & $\mathrm{N} / \mathrm{C}$ & $\mathrm{N} / \mathrm{C}$ & $\mathrm{N} / \mathrm{C}$ & $\mathrm{N} / \mathrm{C}$ & $\mathrm{N} / \mathrm{C}$ & Drainage \\
\hline \multirow[t]{2}{*}{ C:02:0110 } & $2 a$ & 3 & 3 & 3 & 3 & Aeolian \\
\hline & 4 & 4 & 4 & 4 & 4 & Drainage \\
\hline \multirow[t]{2}{*}{ C:02:0083 } & 3 & 3 & 3 & 3 & 3 & Aeolian \\
\hline & 4 & 4 & 4 & 4 & 4 & Drainage \\
\hline C:02:0059 & 5 & 5 & 5 & 5 & 5 & Aeolian \\
\hline & $\mathrm{N} / \mathrm{C}$ & $\mathrm{N} / \mathrm{C}$ & $\mathrm{N} / \mathrm{C}$ & $\mathrm{N} / \mathrm{C}$ & $\mathrm{N} / \mathrm{C}$ & Drainage \\
\hline C:02:0059 & $2 a$ & 3 & 3 & 3 & 3 & Aeolian \\
\hline & $\mathrm{N} / \mathrm{C}$ & $\mathrm{N} / \mathrm{C}$ & $\mathrm{N} / \mathrm{C}$ & $\mathrm{N} / \mathrm{C}$ & $\mathrm{N} / \mathrm{C}$ & Drainage \\
\hline C:02:0095 & $2 \mathrm{a}$ & 3 & 3 & 3 & 3 & Aeolian \\
\hline & $\mathrm{N} / \mathrm{C}$ & $\mathrm{N} / \mathrm{C}$ & $\mathrm{N} / \mathrm{C}$ & $\mathrm{N} / \mathrm{C}$ & $\mathrm{N} / \mathrm{C}$ & Drainage \\
\hline $\mathrm{C}: 02: 0070$ & $2 \mathrm{a}$ & 3 & 3 & 3 & 3 & Aeolian \\
\hline & $\mathrm{N} / \mathrm{C}$ & $\mathrm{N} / \mathrm{C}$ & $\mathrm{N} / \mathrm{C}$ & $\mathrm{N} / \mathrm{C}$ & $\mathrm{N} / \mathrm{C}$ & Drainage \\
\hline C:02:0033 & $2 \mathrm{a}$ & 3 & 3 & 3 & 3 & Aeolian \\
\hline & 4 & 4 & 4 & 4 & 4 & Drainage \\
\hline
\end{tabular}


Table 3.-Continued

\begin{tabular}{|c|c|c|c|c|c|c|}
\hline Site number & 1952 & 1973 & 1984 & 1996 & 2016 & Classification \\
\hline \multirow[t]{2}{*}{$\mathrm{C}: 02: 0050$} & $2 \mathrm{a}$ & $2 a$ & $2 \mathrm{a}$ & $2 a$ & $2 \mathrm{a}$ & Aeolian \\
\hline & $\mathrm{N} / \mathrm{C}$ & 4 & 4 & 4 & 4 & Drainage \\
\hline \multirow[t]{2}{*}{ C:02:0094 } & $2 \mathrm{a}$ & $2 \mathrm{a}$ & $2 \mathrm{a}$ & $2 \mathrm{a}$ & $2 \mathrm{a}$ & Aeolian \\
\hline & $\mathrm{N} / \mathrm{C}$ & 2 & 2 & 2 & 2 & Drainage \\
\hline \multirow[t]{2}{*}{ C:02:0098 } & 1 & 3 & 1 & 3 & 3 & Aeolian \\
\hline & $\mathrm{N} / \mathrm{C}$ & 4 & 4 & 4 & 4 & Drainage \\
\hline \multirow[t]{2}{*}{ C:02:0097 } & 1 & 3 & 1 & 3 & 3 & Aeolian \\
\hline & $\mathrm{N} / \mathrm{C}$ & 4 & 4 & 4 & 4 & Drainage \\
\hline
\end{tabular}

Table 4. Summary of the number of sites within each aeolian and drainage classification type from 1952 to 2016.

\begin{tabular}{|c|c|c|c|c|c|c|}
\hline Classification & $\begin{array}{c}\text { Drainage } \\
\text { type } 1\end{array}$ & $\begin{array}{c}\text { Drainage } \\
\text { type } 2 \\
\end{array}$ & $\begin{array}{c}\text { Drainage } \\
\text { type } 3\end{array}$ & $\begin{array}{c}\text { Drainage } \\
\text { type } 4\end{array}$ & $\begin{array}{c}\text { Drainage } \\
\mathrm{N} / \mathrm{C}\end{array}$ & $\begin{array}{l}\text { Total of each aeolian } \\
\text { classification type }\end{array}$ \\
\hline Aeolian type 1 & None & $\begin{array}{l}1952=1 \\
1973=0 \\
1984=0 \\
1996=0 \\
2016=0\end{array}$ & None & $\begin{array}{l}1952=1 \\
1973=0 \\
1984=2 \\
1996=0 \\
2016=0\end{array}$ & $\begin{array}{l}1952=5 \\
1973=0 \\
1984=0 \\
1996=0 \\
2016=0\end{array}$ & $\begin{array}{l}1952=7 \\
1973=0 \\
1984=2 \\
1996=0 \\
2016=0\end{array}$ \\
\hline Aeolian type 2a & $\begin{array}{l}1952=0 \\
1973=0 \\
1984=1 \\
1996=1 \\
2016=0\end{array}$ & $\begin{array}{l}1952=1 \\
1973=1 \\
1984=2 \\
1996=1 \\
2016=1\end{array}$ & $\begin{array}{l}1952=0 \\
1973=0 \\
1984=1 \\
1996=1 \\
2016=0\end{array}$ & $\begin{array}{l}1952=6 \\
1973=1 \\
1984=3 \\
1996=3 \\
2016=1\end{array}$ & $\begin{array}{l}1952=5 \\
1973=0 \\
1984=0 \\
1996=0 \\
2016=0\end{array}$ & $\begin{array}{l}1952=12 \\
1973=2 \\
1984=7 \\
1996=6 \\
2016=2\end{array}$ \\
\hline Aeolian type 2c & $\begin{array}{l}1952=0 \\
1973=0 \\
1984=1 \\
1996=1 \\
2016=0\end{array}$ & $\begin{array}{l}1952=1 \\
1973=0 \\
1984=4 \\
1996=5 \\
2016=2\end{array}$ & $\begin{array}{l}1952=1 \\
1973=0 \\
1984=1 \\
1996=1 \\
2016=0\end{array}$ & $\begin{array}{l}1952=1 \\
1973=0 \\
1984=1 \\
1996=1 \\
2016=0\end{array}$ & $\begin{array}{l}1952=4 \\
1973=0 \\
1984=0 \\
1996=0 \\
2016=0\end{array}$ & $\begin{array}{l}1952=7 \\
1973=0 \\
1984=7 \\
1996=8 \\
2016=2\end{array}$ \\
\hline Aeolian type 3 & $\begin{array}{l}1952=0 \\
1973=0 \\
1984=0 \\
1996=0 \\
2016=1\end{array}$ & $\begin{array}{l}1952=1 \\
1973=0 \\
1984=2 \\
1996=2 \\
2016=5\end{array}$ & $\begin{array}{l}1952=1 \\
1973=0 \\
1984=1 \\
1996=1 \\
2016=4\end{array}$ & $\begin{array}{l}1952=3 \\
1973=7 \\
1984=12 \\
1996=14 \\
2016=17\end{array}$ & $\begin{array}{l}1952=4 \\
1973=4 \\
1984=4 \\
1996=4 \\
2016=4\end{array}$ & $\begin{array}{l}1952=9 \\
1973=11 \\
1984=19 \\
1996=21 \\
2016=31\end{array}$ \\
\hline Aeolian type 4 & None & None & None & $\begin{array}{l}1952=1 \\
1973=1 \\
1984=1 \\
1996=1 \\
2016=1\end{array}$ & None & $\begin{array}{l}1952=1 \\
1973=1 \\
1984=1 \\
1996=1 \\
2016=1\end{array}$ \\
\hline Aeolian type 5 & $\begin{array}{l}1952=0 \\
1973=0 \\
1984=2 \\
1996=2 \\
2016=2\end{array}$ & $\begin{array}{l}1952=1 \\
1973=0 \\
1984=2 \\
1996=2 \\
2016=2\end{array}$ & None & $\begin{array}{l}1952=2 \\
1973=0 \\
1984=4 \\
1996=4 \\
2016=4\end{array}$ & $\begin{aligned} 1952 & =15 \\
1973 & =3 \\
1984 & =10 \\
1996 & =10 \\
2016 & =10\end{aligned}$ & $\begin{array}{l}1952=18 \\
1973=3 \\
1984=18 \\
1996=18 \\
2016=18\end{array}$ \\
\hline Aeolian N/C & None & None & None & None & $\begin{array}{l}1952=0 \\
1973=37 \\
1984=0 \\
1996=0 \\
2016=0\end{array}$ & $\begin{array}{l}1952=0 \\
1973=37 \\
1984=0 \\
1996=0 \\
2016=0\end{array}$ \\
\hline $\begin{array}{l}\text { Total of each drainage } \\
\text { classification type }\end{array}$ & $\begin{array}{l}1952=0 \\
1973=0 \\
1984=4 \\
1996=4 \\
2016=3\end{array}$ & $\begin{array}{l}1952=5 \\
1973=1 \\
1984=10 \\
1996=10 \\
2016=10\end{array}$ & $\begin{array}{l}1952=2 \\
1973=0 \\
1984=3 \\
1996=3 \\
2016=4\end{array}$ & $\begin{array}{l}1952=14 \\
1973=9 \\
1984=23 \\
1996=23 \\
2016=23\end{array}$ & $\begin{array}{l}1952=33 \\
1973=44 \\
1984=14 \\
1996=14 \\
2016=14\end{array}$ & $\begin{array}{l}1952=54 \\
1973=54 \\
1984=54 \\
1996=54 \\
2016=54\end{array}$ \\
\hline
\end{tabular}




\section{EXPLANATION}

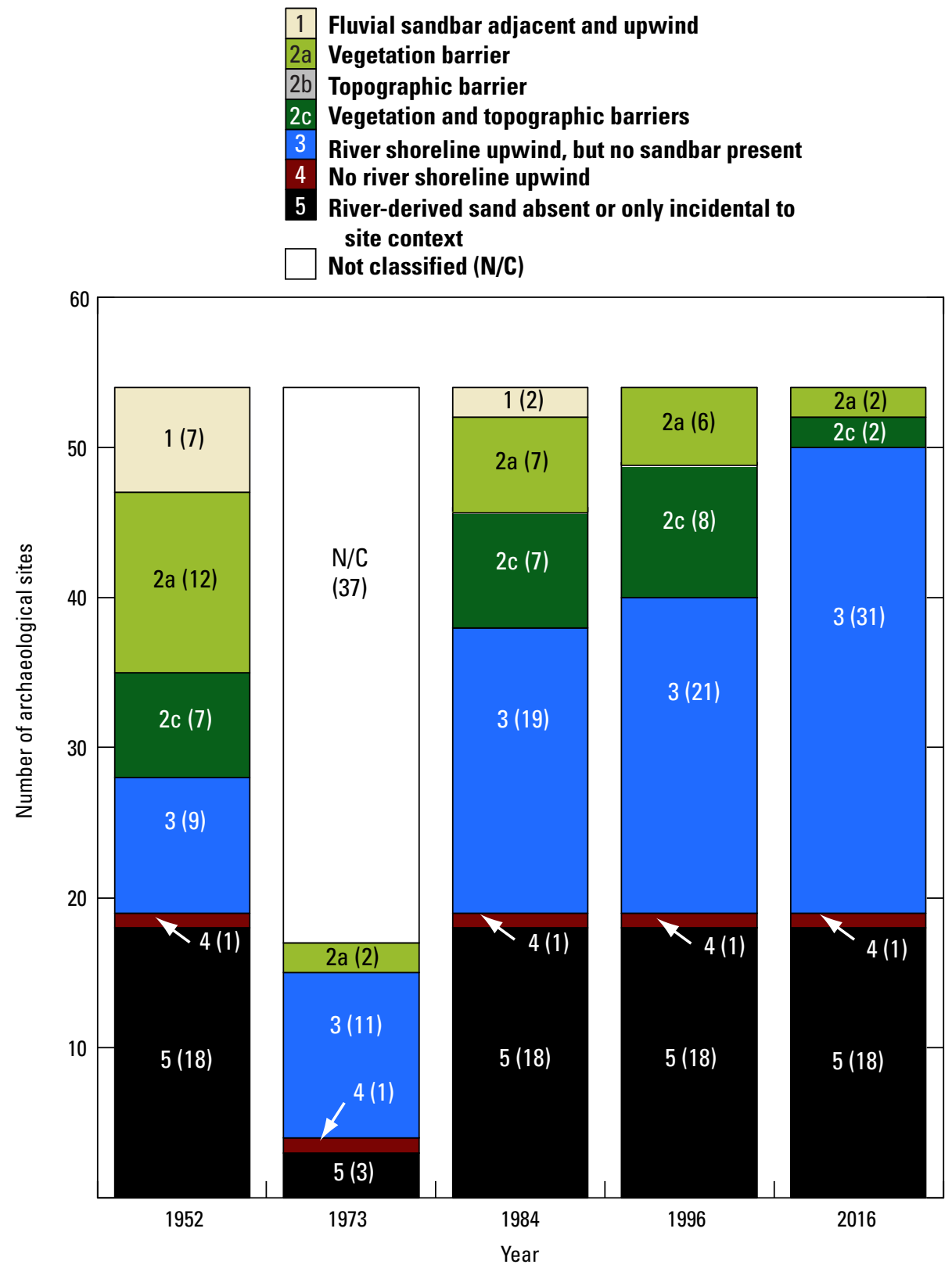

Figure 5. Results of aeolian sand classification for 54 river-corridor archaeological sites in Glen Canyon. Classifications are inferred from available aerial photographs in 1952, 1973, 1984, and 1996 and assessed in the field in 2016. Limited spatial coverage of the 1973 aerial photographs preclude classification of 37 sites. For types 1-4, river-derived sand (fluvial or aeolian) is integral to site context. 
Figure 6. Results of drainage classification for 54 river-corridor archaeological sites in Glen Canyon. Classifications were inferred from available aerial photographs in 1952, 1973, 1984, and 1996 and assessed in the field in 2016. Fourteen of the unclassified sites correspond to those with a type 5 aeolian classification, where the geomorphic context is unrelated to river-derived sand (that is, sites on bedrock or talus). Many other sites remain unclassified because of either limited spatial coverage or low resolution in the aerial photographs.

\section{EXPLANATION}

\section{No drainages}

\section{Terrace-based drainages}

3 Side-canyon-based drainages

\section{River-based drainages}

\section{Not classified (N/C)}

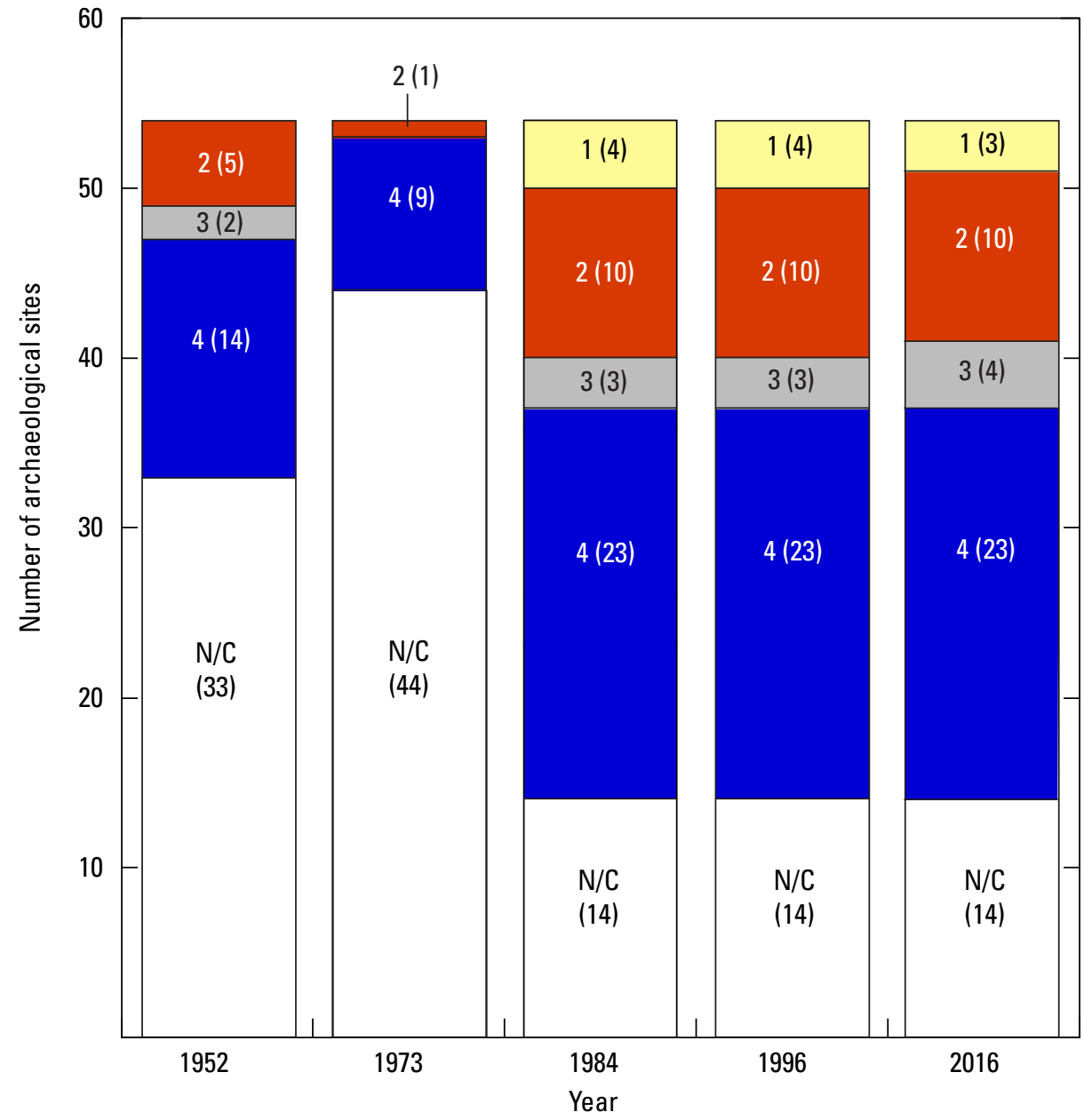

the drainage type for a substantial proportion of the 54 sites, either because of limited available information from aerial photographs or because specific sites had a geomorphic setting for which overland-flow paths would not affect site stability. Fourteen sites remain unclassified in all five years because their geomorphic context is entirely related to bedrock and thus likely not eroding by processes or on time scales relevant to those of dam operations (fig. 6). We were unable to classify an additional 30 sites because of limited aerial photographic coverage in the 1973 set of photographs. Thus, in total, 44 sites were not classified in 1973. Furthermore, the low resolution of the 1952 aerial photographs prevents classification of drainages less than about $3 \mathrm{~m}$ wide. If no drainages were visible at a particular site in the 1952 photographs, we declined to classify the site rather than assume no drainages were present. Owing to this limitation, our interpretation of 1952 drainages includes only arroyo-sized overland-flow paths. Based on this conservative interpretation, 33 sites remain unclassified for 1952 - of which 19 are because of low photographic resolution. The low resolution of the 1952 images, however, did not affect our ability to identify sandbars, which are much larger features than gullies commonly are. Thus, we were able to classify all of the sites with respect to their aeolian type (fig. 5).
During field visits in 2016, we found that an overwhelming majority of the river-corridor archaeological sites have rills, gullies, or arroyos that either intersect or are adjacent to the sites (fig. 6). Most of those overland-flow paths are integrated with the modern Colorado River channel (drainage type 4). Based on our 2016 field observations, only two sites have no drainages and 10 sites have terrace-based drainages (fig. 6). The terrace-based drainages appear to have remained stable (that is, have remained terrace-based drainages) since at least 1984.

In past decades, enough of the river corridor was lined by open, unvegetated fluvial sandbars (though commonly with vegetation on their landward margins) that type 1 and type 2 sites were fairly common (fig. 5), even though the availability of aeolian sand apparently did not lead to dune formation in most places. More recently, however, fluvial sandbars are rare enough in Glen Canyon that only four type 2 sites were present in 2016. All four were affected by vegetation barriers and two sites also have topographic barriers that may limit aeolian sand transport to archaeological sites (two type 2a sites and two type $2 \mathrm{c}$ sites in 2016; fig. 5). Our results show that, since 1952, the total proportion of the 54 archaeological sites with an upwind aeolian sand source (type 1 and 2) has decreased from 48 percent (26 sites) to 7 percent ( 4 sites). 
We identified two sites that merited type 1 classification in 1984 of the post-dam era. Those two sites, AZ:C:02:0097 and AZ:C:02:0098, which are located downstream of the Paria and Colorado River confluence in uppermost Marble Canyon, are classified as type 1 in 1984 not because of evidence for aeolian sand deposition, but rather because a portion of each site was below the maximum elevation reached by the high spring flow of $1983\left(2,745 \mathrm{~m}^{3} / \mathrm{s}\right)$. In the 1984 photographs those two sites appear to have received sediment by direct fluvial deposition as a result of that high flow. Thus, no sites evidently received windblown sand from a fluvial sandbar source at any time in the past three or more decades.

Although the availability of aeolian sand supply to archaeological sites has changed substantially over the past few decades (fig. 5), our analysis detected little change since 1984 in the overland-flow paths than can erode these sites (fig. 6). Prior to 1984 , the limited resolution and spatial coverage of aerial photographs preclude confident classification of the majority of sites. Of the sites we could classify in 1984, 1996, and 2016, an overwhelming majority (that is, 37 of 40 sites, or 93 percent) have rills, gullies, or arroyos that either intersect or are adjacent to the sites. Most of those overland-flow paths are adjusted to a base level that is the modern Colorado River channel. Currently, only three sites have no drainages and 10 sites have terrace-based drainages (fig. 6; table 3). The drainages at terrace-based sites appear to have remained relatively stable since at least 1984 .

We identified only two sites that transitioned from a lower to a higher numbered drainage type. Site C:02:0078 appeared to have terrace-based drainages in 1952 (although this interpretation is tentative, given the photographic resolution) that transitioned to river-based drainages by 1984 and site C:02:0013 had no drainages in 1996, but developed a sidecanyon-based drainage by 2013 (interpretation based on aerial photographs because the site could not be visited directly in 2016). Although we identified little change in sites with terracebased drainages, future erosion at these sites could integrate the existing drainages with either side canyons or the mainstem river, causing a dramatic change in the relative base level and potentially decreasing the geomorphic stability of these sites. Future monitoring efforts will indicate whether such drainage integration and destabilization occurs.

\section{Discussion and Conclusions}

The Glen Canyon reach of the Colorado River downstream from Glen Canyon Dam is poorly situated to provide aeolian sand supply to archaeological sites today. Its geomorphic setting, with few large eddies to trap fluvial sand, as well as the pronounced effects of a dam-induced decrease in sediment supply, creates few aeolian sand sources in Glen Canyon. We find that there are currently no sites receiving aeolian sand from a fluvial sandbar located directly upwind and unimpeded by vegetation (no type 1 sites in 2016; fig. 5). This is consistent with our inference from field observations that aeolian processes rarely define the geomorphic context at most sites today and that evidence for recently active aeolian sediment transport is rare in Glen Canyon.

Our examination of aerial photographs indicates that conversion of type 1 or 2 archaeological sites to type 3 (that is, disappearance of an upwind open, unvegetated fluvial sandbar) resulted from a combination of river erosion and vegetation overgrowth of fluvial sand deposits. Because we have not conducted geospatial analyses of those sandbars it is not possible to quantify to what extent each of these factors contributed to the loss of open sandbars. Visual inspection of the aerial photographs suggests, however, that vegetation overgrowth may have been the primary factor. We observed multiple sites at which the shoreline position appeared not to have changed substantially but where previously open sand had become vegetated.

The prevalence of dense vegetation between many archaeological sites and the river today, including most of the type 3 sites in fig. 5, suggests the possibility that vegetation removal could enhance the potential for aeolian sand transport to archaeological sites. Vegetation removal may be feasible by means of tamarisk herbivory and defoliation by the tamarisk beetle, as has occurred in Glen Canyon since 2009 (Sankey and others, 2016), especially if beetle herbivory increases the mortality of tamarisk. Vegetation removal may also be feasibly conducted by human intervention. It is possible that vegetation removal could increase the connectivity between river-channel and upland sedimentary environments, affecting gullying and aeolian sand transport on terrace surfaces. However, even if vegetation loss did increase the potential for aeolian sand delivery to archaeological sites, the geomorphic setting in Glen Canyon, especially the lack of large eddies to trap big fluvial sandbars that could be aeolian sand sources, suggests that erosion via overland flow would continue to be the dominant landscape process. We reiterate that aeolian sand deposition appears not to have been a major landscape-shaping process in the Glen Canyon reach in recent decades, and likely was not in pre-dam time either, given the lack of well-developed aeolian dunes and the geomorphic and hydraulic characteristics of the river corridor. However, the large aeolian sand ramp near RM -1.5 (fig. $2 G$ ) demonstrates that under the right conditions of sediment supply and wind dynamics, aeolian processes can and do substantially affect local areas of the Glen Canyon reach.

At sites with river-based drainages, future monitoring of drainage width and depth through topographic surveys could determine the rate at which those drainages change and could identify archaeological sites that may be affected by future erosion. Even for type 3 or 4 drainages, where base level likely will not decrease in elevation, additional sediment removal by knickpoint migration up the drainage thalweg or backwasting of drainage walls could further destabilize sites and expose as-yet-uncovered archaeological material. We recognize that by classifying each site by the maximum drainage maturity, we have not considered whether terrace-based drainages may mature to become river-based drainages over time. Future monitoring efforts may improve this classification exercise by documenting and classifying individual drainages within each 
site so that it will be possible to discern the maturation of the drainage network.

Tables 4 and 5 summarize the number of archaeological sites that changed classification with respect to aeolian sediment supply or drainage type over the past several decades. Overall, the majority of sites showed either no change in aeolian class or a change from a lower to a higher numbered type - indicating a decreased potential to receive aeolian sand supply. Most sites show no change in drainage type. However, because a large number of sites could not be classified by drainage type in 1952 and 1973, there is substantial uncertainty about the evolution of drainages prior to 1984. Because of this, we are unable to resolve with certainty how base-level fall during mainstem channel incision and sedimentary terrace retreat (especially between 1959 and 1965, concurrently with bed-scouring flows) affected overland-flow paths through Glen Canyon terraces and archaeological sites.

By tracking changes in aeolian sand supply and drainage types over time, we can identify transitions in the overall geomorphic setting at archaeological sites. However, some potentially important geomorphic changes are not captured by this analysis because, although they modify the landscape, they do not result in a change to the classification type. Examples include incision of gullies through pre-dam fluvial deposits and lateral retreat of cutbanks and terrace risers (Grams and others, 2007; East and others, 2016). Therefore, in addition to tracking geomorphic classifications of all sites over time, it is also important to monitor drainages and sand source areas in detail at specific sites in order to detect

Table 5. Summary of changes observed in aeolian and drainage classification types for each time interval between 1952, 1973, 1984, 1996, and 2016. The implication for archaeological site stability for each observed change is also described. Because many archaeological sites remain unclassified in 1973, changes for the time interval from 1952 to 1984 are also included. Three scenarios are possible: (1) $A$ represents a change from a lower to a higher numbered classification type; (2) $B$ represents a change from a higher to a lower numbered classification type; and (3) $C$ represents no change in classification type.

\begin{tabular}{|c|c|c|c|c|}
\hline & \multicolumn{3}{|c|}{ Change observed in drainage classification } \\
\hline & & $\begin{array}{c}A \\
\begin{array}{c}\text { Increase in drainage classification } \\
\text { type number }\end{array}\end{array}$ & $\begin{array}{c}B \\
\text { Decrease in drainage } \\
\text { classification type number }\end{array}$ & $\begin{array}{c}C \\
\text { No change in drainage classification } \\
\text { type (includes unclassified sites) }\end{array}$ \\
\hline \multirow{9}{*}{ 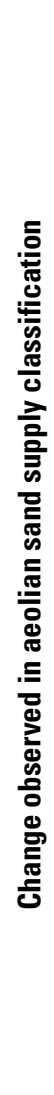 } & \multirow{3}{*}{$\begin{array}{c}\boldsymbol{A} \\
\text { Increase in aeolian } \\
\text { classification type } \\
\text { number }\end{array}$} & $\begin{array}{l}1952 \text { to } 1973: 0 \text { sites } \\
1952 \text { to } 1984: 1 \text { site } \\
1973 \text { to } 1984: 0 \text { sites } \\
1984 \text { to } 1996: 0 \text { sites } \\
1996 \text { to } 2016: 1 \text { site } \\
\end{array}$ & $\begin{array}{l}1952 \text { to } 1973: 0 \text { sites } \\
1952 \text { to } 1984: 0 \text { sites } \\
1973 \text { to } 1984: 0 \text { sites } \\
1984 \text { to } 1996: 0 \text { sites } \\
1996 \text { to } 2016: 0 \text { sites }\end{array}$ & $\begin{array}{l}1952 \text { to } 1973: 10 \text { sites } \\
1952 \text { to } 1984: 15 \text { sites } \\
1973 \text { to } 1984: 0 \text { sites } \\
1984 \text { to } 1996: 3 \text { sites } \\
1996 \text { to } 2016: 9 \text { sites }\end{array}$ \\
\hline & & \multicolumn{3}{|c|}{ Interpretation } \\
\hline & & $\begin{array}{c}\text { Transition to increased erosion by } \\
\text { overland flow and decreased } \\
\text { deposition of windblown sand }\end{array}$ & $\begin{array}{l}\text { Transition to decreased erosion } \\
\text { by overland flow and decreased } \\
\text { deposition of windblown sand }\end{array}$ & $\begin{array}{c}\text { No change in erosion by overland } \\
\text { flow; decreased deposition of } \\
\text { windblown sand }\end{array}$ \\
\hline & \multirow{3}{*}{$\begin{array}{c}B \\
\text { Decrease in aeolian } \\
\text { classification type } \\
\text { number }\end{array}$} & $\begin{array}{l}1952 \text { to } 1973: 0 \text { sites } \\
1952 \text { to } 1984: 0 \text { sites } \\
1973 \text { to } 1984: 0 \text { sites } \\
1984 \text { to } 1996: 0 \text { sites } \\
1996 \text { to } 2016: 0 \text { sites }\end{array}$ & $\begin{array}{l}1952 \text { to } 1973: 0 \text { sites } \\
1952 \text { to } 1984: 0 \text { sites } \\
1973 \text { to } 1984: 0 \text { sites } \\
1984 \text { to } 1996: 0 \text { sites } \\
1996 \text { to } 2016: 0 \text { sites }\end{array}$ & $\begin{array}{l}1952 \text { to } 1973: 0 \text { sites } \\
1952 \text { to } 1984: 5 \text { sites } \\
1973 \text { to } 1984: 2 \text { sites } \\
1984 \text { to } 1996: 1 \text { site } \\
1996 \text { to } 2016: 0 \text { sites }\end{array}$ \\
\hline & & \multicolumn{3}{|c|}{ Interpretation } \\
\hline & & $\begin{array}{l}\text { Transition to increased erosion } \\
\text { by overland flow and increased } \\
\text { deposition of windblown sand }\end{array}$ & $\begin{array}{l}\text { Transition to decreased erosion } \\
\text { by overland flow and increased } \\
\text { deposition of windblown sand }\end{array}$ & $\begin{array}{l}\text { No change in erosion by overland } \\
\text { flow; increased deposition of } \\
\text { windblown sand }\end{array}$ \\
\hline & \multirow{3}{*}{$\begin{array}{l}C \\
\text { No change in aeolian } \\
\text { classification type }\end{array}$} & $\begin{array}{l}1952 \text { to } 1973: 0 \text { sites } \\
1952 \text { to } 1984: 0 \text { sites } \\
1973 \text { to } 1984: 0 \text { sites } \\
1984 \text { to } 1996: 0 \text { sites } \\
1996 \text { to } 2016: 0 \text { sites }\end{array}$ & $\begin{array}{l}1952 \text { to } 1973: 0 \text { sites } \\
1952 \text { to } 1984: 0 \text { sites } \\
1973 \text { to } 1984: 0 \text { sites } \\
1984 \text { to } 1996: 0 \text { sites } \\
1996 \text { to } 2016: 0 \text { sites }\end{array}$ & $\begin{array}{l}1952 \text { to } 1973: 7 \text { sites } \\
1952 \text { to } 1984: 33 \text { sites } \\
1973 \text { to } 1984: 15 \text { sites } \\
1984 \text { to } 1996: 50 \text { sites } \\
1996 \text { to } 2016: 43 \text { sites }\end{array}$ \\
\hline & & \multicolumn{3}{|c|}{ Interpretation } \\
\hline & & $\begin{array}{l}\text { Transition to increased erosion by } \\
\text { overland flow; deposition of } \\
\text { windblown sand remains constant }\end{array}$ & $\begin{array}{l}\text { Transition to decreased erosion } \\
\text { by overland flow; deposition of } \\
\text { windblown sand remains constant }\end{array}$ & $\begin{array}{c}\text { No change in erosion by overland } \\
\text { flow; deposition of windblown } \\
\text { sand remains constant }\end{array}$ \\
\hline
\end{tabular}


future landscape destabilization or degradation. This may be accomplished, for example, through annual (or longer interval) field campaigns that use surveying techniques, such as total-station topographic surveys, structure-from-motion photogrammetry, or ground-based lidar surveys. Terrestrial lidar has been used previously to measure the areal and volumetric extent of geomorphic change at individual sites in Glen, Marble, and Grand Canyons (Collins and others, 2008, 2012; East and others, 2016). These methods can be used to identify whether sites destabilize further in the future owing to knickpoint migration along drainages, sediment loss from backwasting of gully and arroyo walls, or integration of drainages with more mature drainage networks.

The overarching goal of the classification analysis we perform here is to address (1) what number and proportion of archaeological sites in the Colorado River corridor potentially receive aeolian sand supply from sandbars replenished by controlled floods and (2) whether archaeological sites erode or change faster or in a significantly different manner than they would if the dam were operated differently. Our findings indicate that no Glen Canyon archaeological sites in the river corridor downstream from Glen Canyon Dam are ideally situated to received windblown sand, given the current rarity of open, unvegetated fluvial sandbars. In fact, only 4 sites (7 percent) likely received any aeolian sand from recent controlled floods in 2012, 2013, and 2014, and sand transport toward these sites was limited by vegetation. This proportion is substantially less than in the pre-dam era, and has been decreasing throughout post-dam time.

Thus, although the actual loss of aeolian sand supply may not have caused major geomorphic destabilization (given that aeolian processes were not widespread in Glen Canyon even in pre-dam time), there is no reason to expect that aeolian deposition today can mitigate or anneal any of the erosion caused by overland flow. We find no evidence that fluvial sandbars (and the controlled floods intended to enlarge them) provide any beneficial effect today to Glen Canyon archaeological sites through increased aeolian sediment supply. Uncertainty about drainage configurations in 1952 and 1973 limits our ability to discern whether sites erode or change faster or in a different manner than they would if the dam were operated differently than it has been. However, field observations suggest that ongoing lateral terrace retreat may eventually result in conversion of terrace-based drainages to river-based drainages at 10 archaeological sites if the cutbanks retreat far enough laterally to intersect the existing drainages. Even for sites at which the drainage configuration has not yet adjusted to a new lower base level, the extent of erosion by overland flow would need to be monitored by topographic surveys to determine whether site conditions degrade significantly in the future.

\section{Acknowledgments}

This study was supported by funding from the Bureau of Reclamation provided to the U.S. Geological Survey Grand Canyon Monitoring and Research Center. We thank Nathaniel Baker, Brian Harmon, and Rosemary Sucec of the National Park Service Glen Canyon National Recreation Area for valuable discussions during field site visits. Nathaniel Baker and Brian Harmon also provided constructive reviews of this manuscript. We thank Seth Felder, David Foster, and Carol Fritzinger for their logistical support during fieldwork and Meredith Hartwell for curating archival aerial photographs. We thank Monica Erdman, U.S. Geological Survey, for her conscientious editorial work.

\section{References Cited}

Anderson, K.C., 2006, Geoarchaeological investigations of 53 sites between Glen Canyon Dam and Paria Riffle: Report prepared for Bureau of Reclamation, Navajo Nation Archaeology Department Report No. 05-229, 75 p.

Anderson, K.C., and Neff, T., 2011, The influence of paleofloods on archaeological settlement patters during A.D. 1050-1170 along the Colorado River in the Grand Canyon, Arizona, USA: Catena, v. 85, p. 168-186, https://doi.org/10.1016/j. catena.2010.12.004.

Bursztyn, N., Pederson, J.L., Tressler, C., Mackley, R.D., and Mitchell, K.J., 2015, Rock strength along a fluvial transect of the Colorado Plateau — quantifying a fundamental control on geomorphology: Earth and Planetary Science Letters, v. 429, p. 90-100, https://doi.org/10.1016/j.epsl.2015.07.042.

Caster, J., Dealy, T., Andrews, T., Fairley, H., Draut, A., and Sankey, J., 2014, Meteorological data for selected sites along the Colorado River corridor, Arizona, 2011-13: U.S. Geological Survey Open-File Report 2014-1247, 56 p., http://dx.doi. org/10.3133/ofr20141247.

Caster, J., and Sankey, J.B., 2016, Variability in rainfall at monitoring stations and derivation of a long-term rainfall intensity record in the Grand Canyon region, Arizona, USA: U.S. Geological Survey Scientific Investigations Report 2016-5012, 38 p., http://dx.doi.org/10.3133/sir20165012.

Collins, B.D., Bedford, D.R., Corbett, S.C., CronkiteRatcliff, C., and Fairley, H.C., 2016, Relations between rainfall-runoff-induced erosion and aeolian deposition at archaeological sites in a semi-arid dam-controlled river corridor: Earth Surface Processes and Landforms, v. 41, p. 899-917, http://dx.doi.org/10.1002/esp.3874. 
Collins, B.D., Brown, K.M., and Fairley, H.C., 2008, Evaluation of terrestrial LIDAR for monitoring geomorphic change at archeological sites in Grand Canyon National Park, Arizona: U.S. Geological Survey Open-File Report 2008-1384, 60 p., https://pubs.usgs.gov/of/2008/1384.

Collins, B.D., Corbett, S.C., Fairley, H.C., Minasian, D., Kayen, R., Dealy, T.P., and Bedford, D.R., 2012, Topographic change detection at select archeological sites in Grand Canyon National Park, Arizona, 2007-2010: U.S. Geological Survey Scientific Investigations Report 2012-5133, 77 p., https:// pubs.usgs.gov/sir/2012/5133.

Collins, B.D., Corbett, S.C., Sankey, J.B., and Fairley, H.C., 2014, High-resolution topography and geomorphology of select archeological sites in Glen Canyon National Recreation Area, Arizona: U.S. Geological Survey Scientific Investigations Report 2014-5126, 31 p., http://dx.doi. org/10.3133/sir20145126.

Collins, B.D., Minasian, D., and Kayen, R., 2009, Topographic change detection at select archeological sites in Grand Canyon National Park, Arizona, 2006-2007: U.S. Geological Survey Scientific Investigations Report 2009-5116, 58 p., https://pubs.usgs.gov/sir/2009/5116.

Cross, W.F., Baxter, C.V., Rosi-Marshall, E.J., Hall, R.O., Jr., Kennedy, T.A., Donner, K.C., Kelly, H.A.W., Seegert, S.E.Z., Behn, K.E., and Yard, M.D., 2013, Food-web dynamics in a large river discontinuum: Ecological Monographs, v. 83, p. 311-337, http://dx.doi.org/ 10.1890/12-1727.1.

Draut, A.E., 2012, Effects of river regulation on aeolian landscapes, Colorado River, southwestern USA: Journal of Geophysical Research-Earth Surface, v. 117, F02022, http:// dx.doi.org/10.1029/2011JF002329.

Draut, A.E., and Rubin, D.M., 2008, The role of eolian sediment in the preservation of archeologic sites along the Colorado River corridor in Grand Canyon National Park, Arizona: U.S. Geological Survey Professional Paper 1756, 71 p., http:// pubs.usgs.gov/pp/1756/.

Draut, A.E., Rubin, D.M., Dierker, J.L., Fairley, H.C., Griffiths, R.E., Hazel, J.E., Jr., Hunter, R.E., Kohl, K., Leap, L.M., Nials, F.L., Topping, D.J., and Yeatts, M., 2008, Application of sedimentary-structure interpretation to geoarchaeological investigations in the Colorado River corridor, Grand Canyon, Arizona, USA: Geomorphology, v. 101, p. 497-509, https:// doi.org/10.1016/j.geomorph.2007.04.032.

Durning, L.E., Sankey, J.B., Davis, P.A., and Sankey, T.T., 2016, Four-band image mosaic of the Colorado River corridor downstream of Glen Canyon Dam in Arizona, derived from the May 2013 airborne image acquisition: U.S. Geological Survey Data Series 1027, https://doi.org/10.3133/ds1027.
East, A.E., Collins, B.D., Sankey, J.B., Corbett, S.C., Fairley, H.C., and Caster, J., 2016, Conditions and processes affecting sand resources at archeological sites in the Colorado River corridor below Glen Canyon Dam, Arizona: U.S. Geological Survey Professional Paper 1825, 104 p., http://dx.doi.org/10.3133/ pp1825.

Fairley, H.C., 2005, Cultural resources in the Colorado River corridor, chapter 11 of Gloss, S.P., Lovich, J.E., and Melis, T.S., eds., The state of the Colorado River ecosystem in Grand Canyon: U.S. Geological Survey Circular 1282, p. 177-192.

Fairley, H.C., and Hereford, R., 2002, Geoarchaeology of the Colorado River in Grand Canyon, chap. 5 of Phillips, D.A., Jr., and Ware, J.A., eds., Culture and environment in the American Southwest-Essays in honor of Robert C. Euler: Phoenix, Ariz., SWCA Inc., Anthropological Research Paper no. 8, p. 39-48.

Fairley, H.C., Bungart, P.W., Coder, C.M., Huffman, J., Samples, T.L., and Balsom, J.R., 1994, The Grand Canyon river corridor survey project-Archeological survey along the Colorado River between Glen Canyon Dam and Separation Canyon: Report prepared for Grand Canyon National Park Service, Cooperative Agreement No. 9AA-40-07920, 276 p.

Grams, P.E., Schmidt, J.C., and Topping, D.J., 2007, The rate and pattern of bed incision and bank adjustment on the Colorado River in Glen Canyon downstream from Glen Canyon Dam, 1956-2000: Geological Society of America Bulletin, v. 119, p. $556-575$.

Griffiths, P.G., Webb, R.H., and Melis, T.S., 2004, Frequency and initiation of debris flows in Grand Canyon, Arizona: Journal of Geophysical Research, v. 109, F04002, http://dx.doi. org/10.1029/2003JF000077.

Hazel, J.E., Jr., Topping, D.J., Schmidt, J.C., and Kaplinski, M., 2006, Influence of a dam on fine-sediment storage in a canyon river: Journal of Geophysical Research, v. 111, F01025, http:// dx.doi.org/10.1029/2004JF000193.

Hereford, R., Burke, K.J., and Thompson, K.S., 2000, Map showing Quaternary geology and geomorphology of the Granite Park area, Grand Canyon, Arizona: U.S. Geological Survey Geologic Investigations Series I-2662, scale 1:2,000, available at https://pubs.usgs.gov/imap/i2662.

Hereford, R., Fairley, H.C., Thompson, K.S., and Balsom, J.R., 1993, Surficial geology, geomorphology, and erosion of archeologic sites along the Colorado River, eastern Grand Canyon, Grand Canyon National Park, Arizona: U.S. Geological Survey Open-File Report 93-517, 46 p.

Kennedy, T.A., and Ralston, B.E., 2012, Regulation leads to increases in riparian vegetation, but not direct allochthonous inputs, along the Colorado River in Grand Canyon, Arizona: River Research and Application, v. 28, p. 2-12, http://dx.doi. org/10.1002/rra.1431. 
Lancaster, N., 1994, Controls on aeolian activity-some new perspectives from the Kelso Dunes, Mojave Desert, California: Journal of Arid Environments, v. 27, p. 113-125, https://doi.org/10.1006/jare.1994.1052.

Lancaster, N., 1995, Geomorphology of desert dunes: London, Routledge, 290 p.

Leap. L.M., Kunde, J.L., Hubbard, D.C., Andrews, N., Downum, C.E., Miler, A., and Balsom, J.R., 2000, Grand Canyon Monitoring Project 1992-1999-Synthesis and Annual Monitoring Report FY99: Report prepared for Bureau of Reclamation, Grand Canyon National Park River Corridor Monitoring Project Report No. 66, 285 p.

McGuinn-Robbins, D.K., 1995, Comparison of the number and area of backwaters associated with the Colorado River in Glen, Marble, and Grand Canyons, Arizona-Draft: Report prepared for Bureau of Reclamation Glen Canyon Environmental Studies, Contract No. 9-FC-40-07940, 26 p., available at https://www.gcmrc.gov/library/reports/physical/ hydrology/McGuinn-Robbins1995.pdf.

Melis, T.S., ed., 2011, Effects of three high-flow experiments on the Colorado River ecosystem downstream from Glen Canyon Dam, Arizona, U.S. Geological Survey Circular 1366, 147 p., http://pubs.usgs.gov/circ/1366/.

Melis, T.S., Webb, R.H., Griffiths, P.G., and Wise, T.J., 1994, Magnitude and frequency data for historic debris flows in Grand Canyon National Park and vicinity, Arizona: U.S. Geological Survey Water-Resources Investigations Report 94-4214, 285 p., available at https://pubs.usgs.gov/ wri/1994/4214/report.pdf.

Pederson, J.L., and O'Brien, G.R., 2014, Patterns in the landscape and erosion of cultural sites along the Colorado River corridor in Grand Canyon, USA: Geoarchaeology, v. 29, p. 431-447, http://dx.doi.org/ 10.1002/gea.21490.

Pederson, J.L., O’Brien, G., Neff, T., and Spurr, K., 2011, Grand Canyon geoarchaeology project-report on data recovery at nine cultural sites in Grand Canyon and Lower Glen Canyon, 2008-2010: Report prepared for Bureau of Reclamation, $560 \mathrm{p}$.

Pederson, J. L., Petersen, P.A., and Dierker, J.L., 2006, Gullying and erosion control at archeological sites in Grand Canyon, Arizona: Earth Surface Processes and Landforms, v. 31, p. 507-525, http://dx.doi.org/ 10.1002/esp.1286.

Rubin, D.M., and Carter, C.L., eds., 2006, Cross-bedding, bedforms, and paleocurrents in animation ( $2 \mathrm{~d}$ ed.): Tulsa, Oklahoma, SEPM [Society for Sedimentary Geology], 187 p.

Rubin, D.M., Topping, D.J., Schmidt, J.C., Hazel, J.E., Jr., Kaplinski, M., and Melis, T.S., 2002, Recent sediment studies refute Glen Canyon Dam hypothesis: Eos, Transactions American Geophysical Union, v. 83, p. 273-278.
Sankey, J.B., and Draut, A.E., 2014, Gully annealing by aeolian sediment - Field and remote-sensing investigation of aeolianhillslope-fluvial interactions, Colorado River corridor, Arizona, USA: Geomorphology, v. 220, p. 68-80, https://doi. org/10.1016/j.geomorph.2014.05.028.

Sankey, J.B., Ralston, B.E., Grams, P.E., Schmidt, J.C., and Cagney, L.E., 2015, Riparian vegetation, Colorado River, and climate - Five decades of spatiotemporal dynamics in the Grand Canyon with river regulation: Journal of Geophysical Research—Biogeosciences, v. 120, p. 1532-1547, http://dx.doi. org/10.1002/2015JG002991.

Sankey, T.T., Sankey, J.B., Horne, R., and Bedford, A., 2016, Remote sensing of tamarisk biomass, insect herbivory, and defoliation - Novel methods in the Grand Canyon region, Arizona: Photogrammetric Engineering and Remote Sensing, v. 82, p. 645-652, https://doi.org/10.14358/PERS.82.8.645.

Schmidt, J.C., and Graf, J.B., 1990, Aggradation and degradation of alluvial sand deposits, 1965 to 1986, Colorado River, Grand Canyon National Park, Arizona: U.S. Geological Survey Professional Paper 1493, 74 p., http://pubs.er.usgs.gov/ usgspubs/citfor/pp/pp1493.

Schmidt, J.C., and Grams, P.E., 2011, The high flows-Physical science results, chap. 3 of Melis, T.S., ed., Effects of three highflow experiments on the Colorado River ecosystem downstream from Glen Canyon Dam, Arizona: U.S. Geological Survey Circular 1366, p. 53-92, http://pubs.usgs.gov/circ/1366/.

Spurr, K. and Collette, J.H., 2007, Condition assessment and significance evaluation for cultural resources between Glen Canyon Dam and Paria Riffle, Glen Canyon National Recreation Area, Arizona: Report prepared for Bureau of Reclamation, Navajo Nation Archaeology Department Report No. 05-123, 199 p.

Thompson, K.S., and Potochnik, A.R., 2000, Development of a geomorphic model to predict erosion of pre-dam Colorado River terraces containing archeological resources: SWCA, Inc. report prepared for Grand Canyon Monitoring and Research Center, Cultural Resources Report 99-257, 227 p., available at http://www.riversimulator.org/Resources/GCMRC/Cultural/ Thompson2000b.pdf.

Topping, D.J., Rubin, D.M., and Vierra, L.E., Jr., 2000, Colorado River sediment transport-1. Natural sediment supply limitation and the influence of Glen Canyon Dam: Water Resources Research, v. 36, p. 515-542, http://dx.doi. org/10.1029/1999WR900285.

Topping, D.J., Schmidt, J.C., and Vierra, L.E., Jr., 2003, Computation and analysis of the instantaneous-discharge record for the Colorado River at Lees Ferry, Arizona-May 8, 1921, through September 30, 2000: U.S. Geological Survey Professional Paper 1677, 118 p., https://pubs.usgs.gov/pp/pp1677. 


\section{Modern Landscape Processes Affecting Archaeological Sites along the Colorado River Corridor, Arizona}

Turner, R.M., and Karpiscak, M.M., 1980, Recent vegetation changes along the Colorado River between Glen Canyon Dam and Lake Mead, Arizona: U.S. Geological Survey Professional Paper 1132, $125 \mathrm{p}$.

U.S. Geological Survey, 2017, USGS 09380000 Colorado River at Lees Ferry, AZ: U.S. Geological Survey National Water Information System, accessed March 1, 2017, at https://waterdata.usgs.gov/usa/nwis/uv?09380000.
Webb, R.H., Melis, T.S., and Griffiths, P.G., 2003, Debris flows and the Colorado River in Beus, S.S., and Morales, M., eds., Grand Canyon Geology (2d eds): New York, Oxford University Press, p. 371-390.

Wulf, L. and Moss, J., 2004, Archaeological site monitoring and management along the Colorado River corridor below Glen Canyon Dam: National Park Service Resource Management Division FY2004 Annual Monitoring Report, 120 p. 
Menlo Park Publishing Service Center, California Manuscript approved July 20, 2017

Edited by Monica Erdman

Layout by Cory Hurd 
